Working Paper

WP no 714

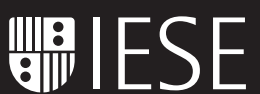

November, 2007

University of Navarra

\title{
110 COMMON ERRORS IN COMPANY VALUATIONS
}

\author{
Pablo Fernández
}

Andrada Bilan 


\title{
110 COMMON ERRORS IN COMPANY VALUATIONS
}

\author{
Pablo Fernández ${ }^{1}$
}

Andrada Bilan ${ }^{2}$

\begin{abstract}
This paper contains a classified collection of 110 errors seen in company valuations performed by financial analysts, investment banks and financial consultants. The author had access to most of the valuations referred to in this paper in his capacity as a consultant in company acquisitions, sales, mergers, and arbitrage processes.

We classify the errors into six main categories: 1) Errors in the discount rate calculation and concerning the riskiness of the company; 2) Errors when calculating or forecasting the expected cash flows; 3) Errors in the calculation of the residual value; 4) Inconsistencies and conceptual errors; 5) Errors when interpreting the valuation; and 6) Organizational errors.
\end{abstract}

\footnotetext{
${ }^{1}$ Professor, Financial Management, PricewaterhouseCoopers Chair of Finance, IESE

${ }^{2}$ Research Assistant, IESE

JEL Classification: G12, G31, M21
}

Keywords: company valuation, valuation errors, valuation. 


\section{COMMON ERRORS IN COMPANY VALUATIONS}

\section{Introduction}

This paper contains a classification of these 110 errors providing at least one example of each, taken from actual valuations.

The sections of the paper are as follows:

1. Errors in the discount rate calculation and concerning the riskiness of the company

2. Errors when calculating or forecasting the expected cash flows

3. Errors in the calculation of the residual value

4. Inconsistencies and conceptual errors

5. Errors when interpreting the valuation

6. Organizational errors

Appendix 1. List of the 110 errors

Appendix 2. A valuation containing multiple errors using an ad hoc method

References

\section{Errors in the discount rate calculation and concerning the riskiness of the company}

\section{A. Wrong risk-free rate used for the valuation}

1. A.1. Using the historical average of the risk-free rate as the actual risk-free rate. Example taken from a financial consultant: "The best estimate of the risk-free rate to use in the CAPM is the historical average of the US risk-free rate from 1928 until today.” 
This is patently absurd. Any student who used an average historical rate from 1928 to 2001 in a university examination (not to mention in an MBA) would be failed on the spot. The risk-free rate is, by definition, the rate that can currently be obtained (at the time when Ke is calculated) by buying risk-free government bonds now. Expectations and forecasts have little to do with the past, or with an average historical rate.

1. A.2. Using the short-term government bond rate as the meaningful risk-free rate in a valuation. Example taken from a financial consultant: "The best estimate of the risk-free rate to use in the CAPM is the return of 90-day US Treasury Bills."

The correct way to calculate a company's cost of capital is to use the rate (Yield or IRR) of long-term government bonds (using bonds of similar duration to that of the expected cash flows) at the time of calculating Ke.

1. A.3. Wrong calculation of the real risk-free rate. Example: "the real risk-free rate is the difference between the IRR of the 10-year Government bonds and the current inflation." To be consistent, we must subtract the expected inflation, not the current inflation.

\section{B. Wrong beta used for the valuation}

1. B.1. Using the historical industry beta, or the average of the betas of similar companies, when the result goes against common sense.

The example of this error comes from a report written by a financial consulting firm. "The purpose of our study has been to make a professional estimate of the fair value at 31 December 2001 of the shares of INMOSEV, an unlisted real estate firm whose main business consists of buying land and building houses for resale. We have assumed a capital contribution by a third party in the amount of 30 million euros in the year 2002, with an estimated return on its investment of 20\%; that is, 6 million euros.

Our study is based essentially on information provided to us by INMOSEV, consisting of historical data and assumptions and hypotheses about estimated future income over the next 11 years.

Table 1 shows the equity cash flows that have been used in this study. The main assumptions and estimates made in applying the valuation method mentioned above are as follows:

Growth rate of the equity cash flows after $2012=1 \%$.

Discount rate. The cost of equity corresponds to the return on long-term risk-free assets, plus the market risk premium, multiplied by a coefficient called beta.

Return on Spanish 15-year government bonds (risk-free return) $=5.00 \%$.

Market risk premium $=4.50 \%$ (source: $\mathrm{BNP}$ Paribas, $\mathrm{SCH}$ ).

Unlevered beta $(\mathrm{Bu})=0.27$. Average of the unlevered betas of listed companies in Spain (see Table 2).

Levered beta $\left(\beta_{\mathrm{L}}\right)$ according to INMOSEV's (average) capital structure $=0.50$.

The average cost of equity is $7.25 \%$.

Consequently, the value of INMOSEV's shares at 31 December 2001 is on the order of approximately 143.09 million euros. 


\section{Table 1}

Main magnitudes of the INMOSEV valuation

\begin{tabular}{|l|c|c|c|c|c|c|}
\cline { 2 - 7 } \multicolumn{1}{c|}{} & Equity cash flow (ECF) & Bu & Ku & BL & Ke & Present value of ECF \\
\hline 2001 & 0 & 0.27 & $6.22 \%$ & & & 0 \\
\hline 2002 & $-30,000$ & 0.27 & $6.22 \%$ & 0.45 & $7.04 \%$ & $-28,026$ \\
\hline 2003 & 0 & 0.27 & $6.22 \%$ & 0.42 & $6.91 \%$ & 0 \\
\hline 2004 & 0 & 0.27 & $6.22 \%$ & 0.50 & $7.26 \%$ & 0 \\
\hline 2005 & 0 & 0.27 & $6.22 \%$ & 0.52 & $7.35 \%$ & 0 \\
\hline 2006 & 0 & 0.27 & $6.22 \%$ & 0.53 & $7.37 \%$ & 0 \\
\hline 2007 & 0 & 0.27 & $6.22 \%$ & 0.57 & $7.55 \%$ & 0 \\
\hline 2008 & 5,631 & 0.27 & $6.22 \%$ & 0.59 & $7.67 \%$ & 3,437 \\
\hline 2009 & 6,401 & 0.27 & $6.22 \%$ & 0.56 & $7.54 \%$ & 3,633 \\
\hline 2010 & 7,184 & 0.27 & $6.22 \%$ & 0.54 & $7.43 \%$ & 3,796 \\
\hline 2011 & 7,963 & 0.27 & $6.22 \%$ & 0.52 & $7.32 \%$ & 3,920 \\
\hline 2012 & 20,501 & 0.27 & $6.22 \%$ & 0.49 & $7.23 \%$ & 9,412 \\
\hline Present value of cash flows from 2013 onward & \multicolumn{5}{|l|}{} \\
\hline
\end{tabular}

From this total we must deduct the margin that the new shareholder who contributes the 30 million euros will earn on the deal (we estimate a figure of around 6 million).

\section{Table 2}

Betas of listed real estate firms in Spain

\begin{tabular}{|l|c|c|c|c|c|c|}
\cline { 2 - 7 } \multicolumn{1}{c|}{} & Vallehermoso & Colonial & Metrovacesa & Bami & Urbis & Average \\
\hline Levered beta & 0.49 & 0.12 & 0.38 & 0.67 & 0.42 & $\mathbf{0 . 4 2}$ \\
\hline Unlevered beta & 0.29 & 0.11 & 0.27 & 0.39 & 0.28 & $\mathbf{0 . 2 7}$ \\
\hline
\end{tabular}

Source: SCH.

The resulting unlevered beta (0.27) is so small that it makes no sense to use it to value any company, let alone an unlisted one. Also, these betas (and any others that might have been used) are arbitrary, as Table 3 shows. If we calculate the betas of the five companies on 31 December 2001 using daily and monthly data and different periods, we can obtain average unlevered betas ranging anywhere from 0.22 to 0.85 . Obviously, a valuation that depends on such a shifting and unreliable variable is contrary to all common sense and prudence. 


\section{Table 3}

Betas calculated at December 31, 2001, with respect to the Madrid Stock Exchange General Index, using daily and monthly data for different periods prior to $31 / 12 / 2001$

\begin{tabular}{|c|c|c|c|c|c|c|c|}
\hline \multirow{2}{*}{ Period } & \multirow[b]{2}{*}{ Data } & \multicolumn{5}{|c|}{ Beta at $31 / 12 / 2001$} & \multirow[b]{2}{*}{ Average } \\
\hline & & Vallehermoso & Colonial & Metrovacesa & Bami & Urbis & \\
\hline \multirow[b]{2}{*}{5 years } & Daily & \multicolumn{2}{|l|}{0.70} & 0.46 & 0.67 & 0.58 & 0.60 \\
\hline & Monthly & \multicolumn{2}{|l|}{0.71} & 0.45 & 1.25 & 1.00 & 0.85 \\
\hline \multirow[b]{2}{*}{4 years } & Daily & \multicolumn{2}{|l|}{0.67} & 0.41 & 0.63 & 0.59 & 0.58 \\
\hline & Monthly & \multicolumn{2}{|l|}{0.58} & 0.43 & 0.95 & 0.80 & 0.69 \\
\hline \multirow[b]{2}{*}{3 years } & Daily & \multicolumn{2}{|l|}{0.60} & 0.31 & 0.51 & 0.48 & 0.48 \\
\hline & Monthly & \multicolumn{2}{|l|}{0.41} & 0.17 & 0.59 & 0.42 & 0.40 \\
\hline \multirow[b]{2}{*}{2 years } & Daily & 0.42 & 0.15 & 0.19 & 0.27 & 0.25 & 0.26 \\
\hline & Monthly & 0.68 & 0.28 & 0.50 & 0.85 & 0.67 & 0.60 \\
\hline \multirow[b]{2}{*}{1 year } & Daily & 0.37 & 0.18 & 0.18 & 0.19 & 0.27 & 0.24 \\
\hline & Monthly & 0.59 & 0.41 & 0.46 & 0.32 & 0.78 & 0.51 \\
\hline \multirow{4}{*}{6 months } & Daily & 0.31 & 0.23 & 0.22 & 0.09 & 0.25 & 0.22 \\
\hline & Monthly & 0.81 & 0.72 & 0.68 & 0.39 & 0.80 & 0.68 \\
\hline & Maximum & 0.81 & 0.72 & 0.68 & 1.25 & 1.00 & 0.85 \\
\hline & Minimum & 0.31 & 0.15 & 0.17 & 0.09 & 0.25 & 0.22 \\
\hline
\end{tabular}

In the end, the shares were sold for 70.4 million euros (instead of 143 million). This is the figure obtained by discounting the flows shown in Table 1 at 9.8\% (rather than at 7.26\%).

1. B.2. Using the historical beta of a company when the result goes against common sense. Historical betas change dramatically, as shown in Campa and Fernández (2004). These authors calculate the betas of 3,813 companies on each day of December 2001 and January 2002, using 60 monthly returns, and report that the maximum beta of a company was, on the average, 15.7 times its minimum beta. The median of the maximum beta divided by the minimum beta was 3.07. The median of the percentage daily change (in absolute value) of the betas was $20 \%$, and the median of the percentage (in absolute value) of the betas was 43\%. Table 3 of this paper and Damodaran (2001, page 72) also show that the calculated betas change dramatically and depend very much on the period used to estimate them.

1. B.3. Assuming that the beta calculated from historical data captures the country risk. Interpretation of the beta of a foreign company listed on the stock market in the USA, taken from an investment bank: "The question is: Does the beta calculated on the basis of the company's share price in New York capture the different premiums for each risk? Our answer is yes, because just as the beta captures changes in the economy and the effect of leverage, it must necessarily absorb the country risk."

There are various ways of including a company's country risk component in the CAPM formula. The most common is to use the spread between the long-term dollar treasury bonds of the country in which the firm operates and long-term U.S. Treasury bonds.

1. B.4. Using the wrong formulae to lever and 'unlever' the beta. Fernández (2004, page 506) shows six different formulae for levering and unlevering the beta. Only three of them are correct, as shown in Fernández (2006a):

- If the debt is expected to be proportional to the book value of equity, the correct relationship between the levered beta $\left(\beta_{\mathrm{L}}\right)$ and the unlevered beta $(\beta u)$ is: $\beta_{\mathrm{L}}=\mathrm{Bu}+(\mathrm{Bu}-$ Bd) D (1 - T) / E. See Fernández (2004a and 2006a). 
- If the debt is expected to be proportional to the market value of equity, the correct relationship between the levered beta $\left(\beta_{\mathrm{L}}\right)$ and the unlevered beta $(\mathrm{Bu})$ is:

$\beta_{L}=\beta u+(\beta u-\beta d)(D / E)[1-T$ Kd / (1+Kd)]. See Miles-Ezzell (1980).

- If the company does not increase its debt, the correct relationship between the levered beta $\left(\beta_{L}\right)$ and the unlevered beta $(\beta u)$ is: $\beta_{L}=\beta u+(\beta u-\beta d)(D-V T S) / E$. See Myers (1974):

Other wrong relationships are:

- Damodaran (1994): $\beta_{\mathrm{L}}=\mathrm{Bu}+\mathrm{Bu} \mathrm{D}(1-\mathrm{T}) / \mathrm{E}$. He uses Fernández (2004a and 2006a) but forgets the beta of the debt.

- Harris-Pringle (1985), Ruback (1995 and 2002): $\beta_{\mathrm{L}}=\beta u+(\beta u-\beta d) D / E$. They use Fernández (2004a and 2006a) but assuming that $\mathrm{T}$ (tax rate) $=0$.

- Practitioners: $\beta_{\mathrm{L}}=\beta u+\beta u$ D / E. They use Fernández (2004a and 2006a) but assuming that $\mathrm{T}$ (tax rate) $=0$, and that $\beta \mathrm{d}=0$.

1. B.5. Arguing that the best estimation of the beta of an emerging market company is the company's beta with respect to the S\&P 500. "The best way to estimate the beta of an emerging economy company with a U.S. stock market listing is through a regression of the return of the share on the return of a U.S. stock market index.”

No, because it is well known (we have plenty of data to confirm this) that companies that are rarely traded have absurdly low calculated betas. Scholes and Williams (1977), for example, warned of this problem and suggested a method for partly getting around it.

There is also the problem of the instability of betas that have been estimated by regression: they are very unstable and depend very much on the data used to calculate them.

Simply using a share's historical beta without analyzing the share and the company's future prospects is very risky, as historical betas are unstable and depend, in almost all companies, on what data we use (daily, weekly, monthly, etc.).

1. B.6. Using the beta of the acquiring company when valuing an acquisition. From the report of an analyst: "As the Target Company is much smaller than the bidder, the Target Company will have almost no influence on the resulting capital structure and the riskiness of the resulting company. Therefore, the relevant beta and the relevant capital structure for the valuation of the Target Company are those of the acquiring company." Wrong: the relevant risk is the risk of the acquired assets. If this was not the case, a Government bond would have a different value for every company.

1. B.7. Using the so-called "book value beta". This calculation uses the net income of a company, instead of the price, in order to compare it with a stock exchange index (for example, IGBM or IBEX35).

The procedure for estimating beta is: $\Delta$ Income $_{a}=a+\beta \Delta$ Income $_{i}$, where. $\Delta$ stands for the variation experienced in the variable during the period. If we use the operating income, we obtain the unlevered beta or the company's beta. If we use the net income, we obtain the levered beta or the shareholders' beta. 
It is quite obvious that such a beta includes the same limitations of the net income and the widespread tendency of using accounting criteria in order to smooth it. In addition, net income is usually calculated once a year (at the end of the financial year), which restrains the available data and, therefore, the explanatory power of the data.

1. B.8. Forgetting the beta of the debt when levering the beta of the shares. An important company from the utilities sector did the following WACC calculation in 2007. The given data was: $\mathrm{Rf}=4 \%$; Risk premium $=5 \%$; Equity ratio=35\%; $\mathrm{Kd}=6,5 \%, \mathrm{~T}=28 \%$; Beta unlevered $=1$. With this set of data and using the wrong formula by Damodaran (1994) which is shown in paragraph 1.B.4, they calculated a levered beta of 2,34, a cost of equity of 15,69\% and a WACC of 8,53\%. Had they used the formula recommended by Fernández (2004c) which is shown in paragraph 1.B.4 and includes the beta of the debt $(0,5)$ the new levered beta would be 1,67 , the cost of equity 12,34\% and the WACC would equal 7,36\%.

1. B.9. Calculating the beta using strange formulae. An example is the following formula used by a financial consulting firm:

$\beta_{L}=\beta_{C} R S+1-R S$, being $\beta_{C}$ the beta calculated in the regression, RS, systematic risk (the $R^{2}$ of the regression) and $B_{\mathrm{L}}$ the levered beta used to obtain the required return to equity.

\section{C. Wrong market risk premium used for the valuation}

1. C.1. Supposing that the required market risk premium is equal to the historical equity risk premium. Table 4 shows that the historical U.S. equity risk premium changes considerably depending on the interval used to calculate it. The required market risk premium (the one used in valuation to determine the required return to equity) is an expectation and has little to do with history.

\section{Table 4}

Historical equity risk premium in the U.S.

\begin{tabular}{|l|r|r|r|}
\cline { 2 - 4 } \multicolumn{1}{c|}{} & \multicolumn{3}{c|}{ Average Annual Returns of } \\
\cline { 2 - 4 } Arithmetic Average & Stocks & T-Bills & T-Bonds \\
\hline $1928-1953$ & $9.46 \%$ & $1.03 \%$ & $2.96 \%$ \\
\hline $1928-1999$ & $12.68 \%$ & $3.92 \%$ & $5.05 \%$ \\
\hline $1928-2002$ & $11.60 \%$ & $3.93 \%$ & $5.35 \%$ \\
\hline $1962-2002$ & $11.19 \%$ & $6.03 \%$ & $7.53 \%$ \\
\hline $1992-2002$ & $10.73 \%$ & $4.40 \%$ & $8.58 \%$ \\
\hline
\end{tabular}

\begin{tabular}{|c|c|}
\hline \multicolumn{2}{|c|}{ Equity Risk Premium } \\
\hline Stocks - T-Bills & Stocks - T-Bonds \\
\hline $8.44 \%$ & $6.51 \%$ \\
\hline $8.76 \%$ & $7.63 \%$ \\
\hline $7.67 \%$ & $6.25 \%$ \\
\hline $5.17 \%$ & $3.66 \%$ \\
\hline $6.32 \%$ & $2.15 \%$ \\
\hline
\end{tabular}

\begin{tabular}{|l|r|r|r|}
\cline { 2 - 4 } \multicolumn{1}{c|}{} & \multicolumn{3}{c|}{ Average Annual Returns of } \\
\cline { 2 - 4 } \multicolumn{1}{c|}{ Geometric Average } & Stocks & T-Bills & T-Bonds \\
\hline $1928-1953$ & $6.49 \%$ & $1.02 \%$ & $2.92 \%$ \\
\hline $1928-1999$ & $10.76 \%$ & $3.87 \%$ & $4.79 \%$ \\
\hline $1928-2002$ & $9.62 \%$ & $3.89 \%$ & $5.09 \%$ \\
\hline $1962-2002$ & $9.90 \%$ & $5.99 \%$ & $7.14 \%$ \\
\hline $1992-2002$ & $9.09 \%$ & $4.40 \%$ & $8.14 \%$ \\
\hline
\end{tabular}

\begin{tabular}{|c|c|}
\hline \multicolumn{2}{|c|}{ Risk Premium } \\
\hline Stocks - T-Bills & Stocks - T-Bonds \\
\hline $5.47 \%$ & $3.57 \%$ \\
\hline $6.89 \%$ & $5.96 \%$ \\
\hline $5.73 \%$ & $4.53 \%$ \\
\hline $3.90 \%$ & $2.76 \%$ \\
\hline $4.69 \%$ & $0.95 \%$ \\
\hline
\end{tabular}

1. C.2. Assuming that the required market risk premium is equal to zero. This argument typically follows the arguments of Mehra and Prescott (1985) and Mehra (2003), who say that 
"stocks and bonds pay off in approximately the same states of nature or economic scenarios, and hence, they should command approximately the same rate of return." Siegel (1998 and 1999) interprets Table 4 by saying: "although it may seem that stocks have more risk than long-term Treasury bonds, this is not true. The safest long-term investment (from the viewpoint of preserving the investor's purchasing power) has been stocks, not Treasury bonds."

1. C.3. Assuming that the required market risk premium is the expected risk premium. Example: In 2004 the risk-free rate was $4.5 \%$ and a financial analyst wrote a report in which he forecast a return for the stock market of $20 \%$. This forecast was used by a financial consulting firm to argue that the required market risk premium for a valuation in Europe was 15,5\% (20\% - 4,5\%).

1. C.4. Using historical, implicit, expected and required risk premiums interchangeably. Fernández (2006b) shows that the concept of risk premium (equity premium or market premium), is used with reference to four different parameters: historical, implicit, expected and required (the one used in valuation is the required risk premium). The above article also states that it is very common to mistake some premiums with the others and even to assume that the four of them are identical.

1. C.5. Using a risk premium recommended by a textbook even though it goes against common sense. Fernández (2006c) revises the most popular valuation books (Brealey and Myers, 2000; Copeland, Koller and Murrin, 2000 (McKinsey); Ross, Westerfield and Jaffe; Bodie, Kane and Marcus; Damodaran; Copeland and Weston; Van Horne; Bodie and Merton; Stowe et al., 2002; Pratt; Penman, 2001; Bruner; Weston and Brigham; Arzac), and emphasizes the differences in their recommendations regarding the risk premium which should be used in valuations. The following chart reflects these findings:

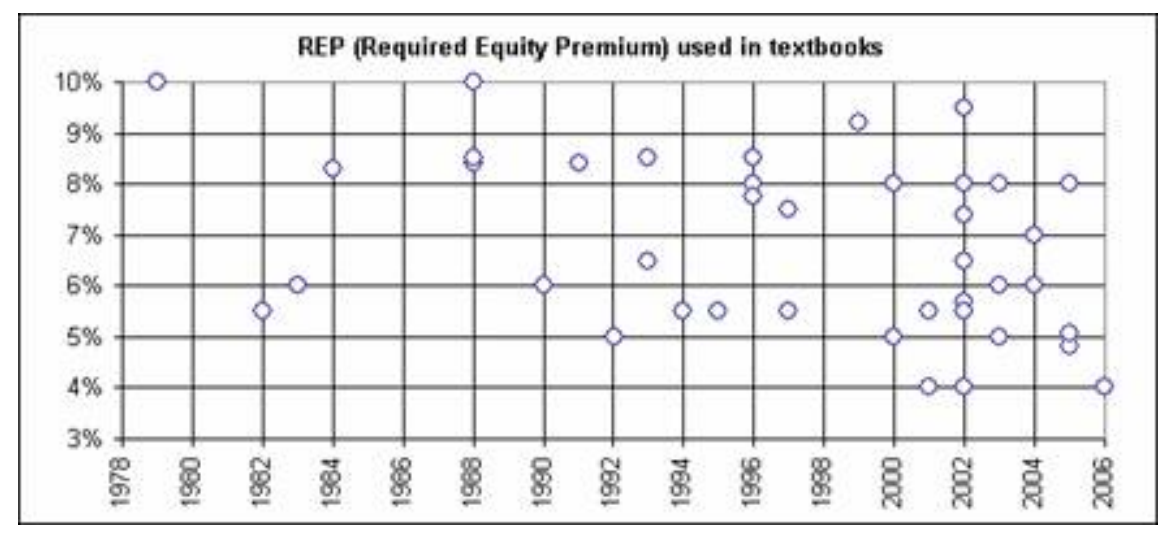

\section{D. Wrong calculation of WACC (Weighted Average Cost of Capital)}

1. D.1. Using the wrong definition of WACC. An example valuation, dated April 2001, of an edible oil company in Ukraine, provided by a leading European investment bank:

"The weighted average cost of capital (WACC) is defined as:

$$
\mathrm{WACC}=\mathrm{R}_{\mathrm{f}}+\mathrm{Bu}\left(\mathrm{Rm}-\mathrm{R}_{\mathrm{f}}\right),
$$

where: $R_{f}=$ risk-free rate; $B u=$ unlevered beta; $R m=$ market risk rate."

The WACC calculated for the Ukrainian company was $14.6 \%$ and the expected free cash flows for the Ukrainian company were: 


\begin{tabular}{|l|c|c|c|c|c|c|c|c|c|}
\hline (Million euros) & 2001 & 2002 & 2003 & 2004 & 2005 & 2006 & 2007 & 2008 & 2009 \\
\hline FCF & 3.7 & 14.7 & 11.9 & -3.0 & 12.9 & 12.9 & 12.6 & 12.6 & 12.6 \\
\hline
\end{tabular}

The reported enterprise value in December 2000 was 71 million euros. This result comes from adding the present value of the 2001-2009 FCFs (45.6) discounted at the $14.6 \%$ plus the present value of the residual value calculated with the FCF of 2009 assuming no growth (25.3).

In fact, (1) is not at all the definition of the WACC. It is the definition of the required return to assets, also known as the cost of unlevered equity $(\mathrm{Ku})$. We also must interpret the term $(\mathrm{Rm}-$ $\mathrm{R}_{\mathrm{f}}$ ) as the required risk premium.

The correct formula for the WACC is:

$$
\begin{aligned}
& \text { WACC }=[\mathrm{D} /(\mathrm{D}+\mathrm{E})] \mathrm{Kd}(1-\mathrm{T})+[\mathrm{E} /(\mathrm{D}+\mathrm{E})] \mathrm{Ke} \\
& \text { where: } \mathrm{Ke}=\mathrm{Ku}+(\mathrm{D} / \mathrm{E})(1-\mathrm{T})(\mathrm{Ku}-\mathrm{Kd})
\end{aligned}
$$

$\mathrm{Kd}=$ Cost of debt. $\mathrm{D}=$ Value of debt. $\mathrm{E}=$ Value of equity. $\mathrm{T}=$ effective corporate tax rate

The valuation of the Ukrainian company used a (wrongly defined) "WACC" of $14.6 \%$. But $14.6 \%$ was the $\mathrm{Ku}$, not the WACC. The 71 million euros was the value of the unlevered equity, not the enterprise value.

On December 2000, the Ukrainian company's debt was 33.7 million euros and the nominal cost of debt was $6.49 \%$. The correct WACC for the Ukrainian company should have been ${ }^{1}$ :

$$
\begin{aligned}
& \mathrm{Ke}=\mathrm{Ku}+(\mathrm{D} / \mathrm{E})(1-\mathrm{T})(\mathrm{Ku}-\mathrm{Kd})=14.6+(33.7 / 48.63)(1-0.3)(14.6-6.49)=18.53 \% \\
& \mathrm{WACC}=[\mathrm{D} /(\mathrm{D}+\mathrm{E})] \mathrm{Kd}(1-\mathrm{T})+[\mathrm{E} /(\mathrm{D}+\mathrm{E})] \mathrm{Ke}=0.409 \times 6.49(1-0.30)+0.591 \times 18.53=12.81 \% \\
& \text { Enterprise value }=\mathrm{E}+\mathrm{D}=\mathrm{PV}(\mathrm{FCF} ; 12.81 \%)=82.33 \text { million euros. }
\end{aligned}
$$

1. D.2. The debt-to-equity ratio used to calculate the WACC is different from the debt-toequity ratio resulting from the valuation. An example is the valuation of a broadcasting company performed by an investment bank (see Table 5), which discounted the expected FCFs at the WACC (10\%) and assumed a constant growth of $2 \%$ after 2008 . The valuation provided lines 1 to 7, and stated that the WACC was calculated assuming a constant Ke of 13.3\% (line 5) and a constant Kd of 9\% (line 6). The WACC was calculated using market values (the equity market value on the valuation date was 1,490 million and the debt value 1,184 million) and the statutory corporate tax rate of 35\%.

The valuation also included the equity value at the end of 2002 (3,033; line 8) and the debt value at the end of 2002 (1,184; line 10). Table 6 provides the main results of the valuation according to the investment bank.

\section{Errors:}

1. Wrong calculation of the WACC. To calculate the WACC, we need to know the evolution of the equity value and the debt value. We calculate the equity value based on the equity value

\footnotetext{
${ }^{1}$ The (D/E) ratios must be calculated using the values obtained in the valuation. 
provided for 2002. The formula that relates the equity value in one year to the equity value in the previous year is $E_{t}=E_{t-1}\left(1+K_{t}\right)-E_{C F}$.

To calculate the debt value, we may use the formula for the increase of debt, shown in line 9. The increase of debt may be calculated if we know the ECF, the FCF, the interest and the effective tax rate. Given line 9, it is easy to fill line 10.

Line 11 shows the debt ratio according to the valuation, which decreases with time.

If we calculate the WACC using lines 4, 5, 6, 8 and 10, we get line 12. The calculated WACC is higher than the WACC assumed and used by the valuer.

Another way of showing the inconsistency of the WACC is to calculate the implicit Ke in a WACC of $10 \%$ using lines 4, 6, 8 and 10. This is shown in line 13. If we are using a WACC of $10 \%$, Ke should be much lower than $13.3 \%$.

2. The capital structure of 2008 is not valid for calculating the residual value because in order to calculate the present value of the FCF growing at $2 \%$ using a single rate, a constant debt to equity ratio is needed.

\section{Table 5}

Valuation of a broadcasting company performed by an investment bank

Data provided by the investment bank in italics

\begin{tabular}{|c|c|c|c|c|c|c|c|}
\hline & 2002 & 2003 & 2004 & 2005 & 2006 & 2007 & 2008 \\
\hline FCF & & -290 & -102 & 250 & 354 & 459 & 496 \\
\hline ECF & & 0 & 0 & 0 & 0 & 34 & 35 \\
\hline Interest expenses & & 107 & 142 & 164 & 157 & 139 & 112 \\
\hline Effective tax rate & & $0.0 \%$ & $0.0 \%$ & $0.0 \%$ & $0.0 \%$ & $12.0 \%$ & $35.0 \%$ \\
\hline $\mathrm{Ke}$ & & $13.3 \%$ & $13.3 \%$ & $13.3 \%$ & $13.3 \%$ & $13.3 \%$ & $13.3 \%$ \\
\hline $\mathrm{Kd}$ & & $9.0 \%$ & $9.0 \%$ & $9.0 \%$ & $9.0 \%$ & $9.0 \%$ & $9.0 \%$ \\
\hline WACC used in the valuation & & $10.0 \%$ & $10.0 \%$ & $10.0 \%$ & $10.0 \%$ & $10.0 \%$ & $10.0 \%$ \\
\hline Equity value (E) & 3,033 & 3,436 & 3,893 & 4,410 & 4,997 & 5,627 & 6,341 \\
\hline$\Delta \mathrm{D}=\mathrm{ECF}-\mathrm{FCF}+\operatorname{Int}(1-\mathrm{T})$ & & 397 & 244 & -86 & -197 & -303 & -389 \\
\hline$1 0 \longdiv { \text { Debt value (D) } }$ & 1,184 & 1,581 & 1,825 & 1,739 & 1,542 & 1,239 & 850 \\
\hline $\mathrm{D} /(\mathrm{D}+\mathrm{E})$ & $28.1 \%$ & $31.5 \%$ & $31.9 \%$ & $28.3 \%$ & $23.6 \%$ & $18.0 \%$ & $11.8 \%$ \\
\hline WACC using lines $4,5,6,8,10$ & & $12.09 \%$ & $11.95 \%$ & $11.93 \%$ & $12.08 \%$ & $12.03 \%$ & $11.96 \%$ \\
\hline 13 Implicit Ke in a WACC of $10 \%$ & & $10.39 \%$ & $10.46 \%$ & $10.47 \%$ & $10.39 \%$ & $10.64 \%$ & $10.91 \%$ \\
\hline
\end{tabular}

\section{Table 6}

Valuation using the wrong WACC of $10 \%$

\begin{tabular}{|l|r|}
\hline Present value in 2002 using a WACC of 10\% \\
\hline Present value in 2002 of the free cash flows 2003-2008 & 647 \\
\hline Present value in 2002 of the residual value $(\mathrm{g}=2 \%)$ & 3,570 \\
\hline Sum & 4,217 \\
\hline Minus debt & $-1,184$ \\
\hline Equity value & 3,033 \\
\hline
\end{tabular}


To perform a correct valuation, assuming a constant WACC from 2009 on, we must recalculate Table 5. Tables 7 and 8 contain the valuation correcting the WACC. To assume a constant WACC from 2009 on, the debt must also increase by $2 \%$ per year (see line 9, 2009). This implies that the ECF (line 2) in 2009 is much higher than the ECF in 2008.

Simply by correcting the error in the WACC, the equity value is reduced from 3,033 to 2,014 (a $33.6 \%$ reduction).

\section{Table 7}

Valuation calculating the WACC correctly

\begin{tabular}{|c|c|c|c|c|c|c|c|c|}
\hline & 2002 & 2003 & 2004 & 2005 & 2006 & 2007 & 2008 & 2009 \\
\hline FCF & & -290 & -102 & 250 & 354 & 459 & 496 & 505.9 \\
\hline ECF & & 0 & 0 & 0 & 0 & 34 & 35 & 473.2 \\
\hline Interest expenses & & 107 & 142 & 164 & 157 & 139 & 112 & 76.5 \\
\hline Effective tax rate & & $0.0 \%$ & $0.0 \%$ & $0.0 \%$ & $0.0 \%$ & $12.0 \%$ & $35.0 \%$ & $35.0 \%$ \\
\hline $\mathrm{Ke}$ & & $13.3 \%$ & $13.3 \%$ & $13.3 \%$ & $13.3 \%$ & $13.3 \%$ & $13.3 \%$ & $13.3 \%$ \\
\hline Kd & & $9.0 \%$ & $9.0 \%$ & $9.0 \%$ & $9.0 \%$ & $9.0 \%$ & $9.0 \%$ & $9.0 \%$ \\
\hline Equity value (E) & 2,014 & 2,282 & 2,586 & 2,930 & 3,320 & 3,727 & 4,187 & 4,271 \\
\hline$\Delta \mathrm{D}=\mathrm{ECF}-\mathrm{FCF}+\operatorname{Int}(1-\mathrm{T})$ & & 397 & 244 & -86 & -197 & -303 & -389 & 17 \\
\hline Debt value (D) & 1,184 & 1,581 & 1,825 & 1,739 & 1,542 & 1,239 & 850 & 867 \\
\hline $\mathrm{D} /(\mathrm{D}+\mathrm{E})$ & $37.0 \%$ & $40.9 \%$ & $41.4 \%$ & $37.2 \%$ & $31.7 \%$ & $25.0 \%$ & $16.9 \%$ & $16.9 \%$ \\
\hline WACC calculated with $4,5,6,8,10$ & & $11.71 \%$ & $11.54 \%$ & $11.52 \%$ & $11.70 \%$ & $11.59 \%$ & $11.44 \%$ & $12.04 \%$ \\
\hline
\end{tabular}

\section{Table 8}

Valuation using the corrected WACC from Table 6

\begin{tabular}{|l|r|}
\hline Present value in 2002 using the WACC calculated in Table 6 \\
\hline Present value in 2002 of the free cash flows 2003-2008 & 588 \\
\hline Present value in 2002 of the residual value $(\mathrm{g}=2 \%)$ & 2,610 \\
\hline Sum & 3,198 \\
\hline Minus debt & $-1,184$ \\
\hline Equity value & 2,014 \\
\hline
\end{tabular}

1. D.3. Using discount rates lower than the risk-free rate. An example is error 3 in Appendix 2. $\mathrm{Ke}$ and $\mathrm{Ku}$ are always higher than the risk-free rate. WACC may be lower than the risk-free rate only for investments with extremely low risk. An example of that may be found in Ruback (1986).

1. D.4. Using the statutory tax rate, instead of the effective tax rate of the levered company. There are many valuations in which the tax rate used to calculate the WACC is the statutory tax rate (normally arguing that the correct tax rate is the marginal tax rate). However this is wrong. The correct tax rate that should be used in order to calculate the WACC, when valuing a company, is the effective tax rate of the levered company every year.

1. D.5. Valuing all the different businesses of a diversified company using the same WACC (same leverage and same Ke).

1. D.6. Considering that WACC/(1-T) is a reasonable return for the company's stakeholders. Some countries assume that a reasonable return on a telephone company's assets is WACC/(1T). Obviously, this is not correct. It could only be valid for non-growing perpetuities and if the return on assets was calculated before taxes. 
1. D.7. Using the wrong formula for the WACC when the value of debt (D) is not equal to its book value (N). Fernández (2002, page 416) shows that the expression for the WACC when the value of debt (D) is not equal to its book value (N) is WACC $=(\mathrm{E} \mathrm{Ke}+\mathrm{D} \mathrm{Kd}-\mathrm{N} \mathrm{r} \mathrm{T}) /(\mathrm{E}+\mathrm{D})$. $\mathrm{Kd}$ is the required return to debt and $\mathrm{r}$ is the cost of debt.

1. D.8. Calculating the WACC assuming a capital structure and deducting the current debt from the enterprise value. This error appears in a valuation by an investment bank. Current debt was 125 , the enterprise value was 2,180 , and the debt-to-equity ratio used to calculate the WACC was $50 \%$.

This is wrong because the outstanding and forecast debt should be used to calculate the WACC. The equity value of a firm is given by the difference between the firm value and the outstanding debt, where the firm value is calculated using the WACC, and the WACC is calculated using the outstanding (market value of) debt. Alternatively, if the firm starts with its current debt and moves towards another round of financing, then a variable WACC (different for each year) should be used, and the current debt should be deducted from the enterprise value.

1. D.9. Calculating the WACC using book values of debt and equity. This is quite a common error. The appropriate values of debt and equity are the ones resulting from the valuation.

1. D.10. Calculating the WACC using strange formulae.

\section{E. Wrong calculation of the value of tax shields}

1. E.1. Discounting the tax shield using the required return to unlevered equity. Many valuers assume, following Ruback (1995 and 2002), that the value of tax shields (VTS) is the present value of tax shields ( $\mathrm{D} \mathrm{Kd} \mathrm{T)} \mathrm{discounted} \mathrm{at} \mathrm{the} \mathrm{required} \mathrm{return} \mathrm{to} \mathrm{unlevered} \mathrm{equity}(\mathrm{Ku})$. Fernández (2004a and 2004b) proves that this expression is incorrect and that the value of tax shields is the present value of $\mathrm{D} \mathrm{Ku} \mathrm{T}$ discounted at the required return to unlevered equity $(\mathrm{Ku})$ : VTS = PV[D Ku T; Ku].

1. E.2. Using odd or ad-hoc formulae. Fernández (2002, page 506) shows different expressions for calculating the value of tax shields that are frequently used and that are supported by some papers in financial literature. Only three of them are correct, as shown in Fernández (2004b):

- If the company expects its debt to be proportional to the equity book value, the value of tax shields is the present value of $\mathrm{D} \mathrm{Ku} \mathrm{T}$ discounted at the required return to unlevered equity (Ku): VTS = PV[D Ku T; Ku]. See Fernández (2004a and 2006a).

- If the company expects its debt to be proportional to the equity market value, the value of tax shields is PV[Ku; D T Kd] $(1+\mathrm{Ku}) /(1+\mathrm{Kd})$. See Miles-Ezzell (1980).

- If the company will not increase its debt, the value of tax shields is: PV[D T Kd; Kd]. See Myers (1974).

Some incorrect formulae for calculating the value of tax shields are:

- Harris-Pringle (1985) and Ruback (1995, 2002): PV[Ku; D T Kd]

- Damodaran (1994): PV[Ku; DTKu - D (Kd- RF) (1-T)]

- Practitioners: PV[Ku; DTKd - D(Kd- $\left.\left.\mathrm{R}_{\mathrm{F}}\right)\right]$ 
1. E.3. Using the Modigliani-Miller formula when it is not appropriate. Myers (1974) and Modigliani-Miller (1963) suggest discounting the expected value of tax shields using the cost of debt or the risk free rate. But this is only valid in the case of perpetual debt and when it is possible to know the certain value of the debt at any future moment.

1. E.4. Using the Milles-Ezzell formula when it is not appropriate. Miles and Ezzell (1980) suggest discounting the expected value of tax shields using the cost of debt, for the tax shields of the first year, and the unlevered cost of equity $(\mathrm{Ku})$, for the following years. But this is true only in the case of debt proportional to the market value of the shares and the author confesses not having any knowledge of a company that manages its debt in such a way.

\section{F. Wrong treatment of country risk}

1. F.1. Not considering the country risk, arguing that it is diversifiable. Example taken from a regulator: "It is not correct to include the country risk of an emerging country because from the perspective of global investors only systematic risk matters, and country-specific events will be uncorrelated with global market movements. Therefore, country-specific events will be unsystematic risk, totally uncorrelated with global market movements." According to this view, the required return to equity will be the same for a US diversified portfolio as for a Bolivian diversified portfolio.

1. F.2. Assuming that a disaster in an emerging market will increase the calculated beta, in relation to the S\&P 500, of the companies in that country. Example taken from a financial consulting firm: "The occurrence of any dramatic systemic event (devaluation, end of convertibility, capital transfer controls, threats to democratic stability) that significantly raises the country risk will lead automatically to a substantial increase in the estimated beta, in relation to the SEP500, of the companies that operate in that country."

No. That is why, when valuing companies in emerging countries, we use the country risk, because the beta no longer captures all the above-mentioned risks: devaluation, end of convertibility, capital transfer controls, threats to democratic stability...

Also, if ADRs have low liquidity (if they are traded only a few times each day and are unlikely to be traded exactly at the close of each session, which is when analysts usually take prices for calculating betas), then the calculated beta will tend towards zero, owing to the nonsynchronous trading effect, which is perfectly described by Scholes and Williams (1977).

1. F.3. Assuming that an agreement with a government agency eliminates country risk. Example taken from an investment bank: "If a government grants a company a monopoly of a particular market, with agreements that guarantee legal and tax stability and economic equilibrium, then there is no country risk (such as devaluation, end of convertibility, capital transfer controls, threats to democratic stability)."

No. The risks of devaluation, end of convertibility, capital transfer controls, threats to democratic stability, etc., remain. No government can eliminate its own risk. That is to say, the shares of a company that operates in a country cannot have less risk than the government bonds of that country. A company's shares would have exactly the same risk as the country's government bonds only if the government was to guarantee and fix future dividends for shareholders. However, that does not usually happen. 
1. F.4. Assuming that the beta provided by Market Guide with the Bloomberg adjustment incorporates the illiquidity risk and the small cap premium. Example taken from an investment bank: "The Market Guide beta captures the distorting effects of the share's low liquidity and the small size of the firm through the so-called Bloomberg adjustment formula."

No. The so-called "Bloomberg adjustment formula" is simply an arbitrary adjustment to make the calculated betas converge towards 1 . The arbitrary adjustment consists of multiplying the calculated beta by 0.67 and adding 0.33 . Adj. Beta $=0.67{ }^{*}$ raw beta +0.33 . It must be stressed that this adjustment is completely arbitrary.

1. F.5. Using odd calculations of the country risk premium. Taken from an investment bank: "In the slide number 83 of Damodaran (downloadable in http://pages.stern.nyu.edu/ adamodar/), Damodaran presents the country risk premium (Adjusted Equity Spread) of Brazil. He starts with the spread of the long-term Government Bonds (4.83\%) and multiplies it by the ratio of the volatility of the Brazilian Index Bovespa (30.64\%) to the volatility of the risk-free debt of Brazil (15.28\%). Then, the Adjusted Equity Spread of Brazil is 9.69\%."

A good paper about valuation in emerging countries is Bruner, Conroy, Estrada, Kritzman and Li (2002).

\section{G. Including an illiquidity, small-cap, or specific premium when it is not appropriate}

1.G.1. Including an odd small-cap premium. Taken from an investment bank: "The Ukrainian country risk has been adjusted to hedge the political risk covered by the insurance company. ${ }^{2}$ The political risk is usually $50 \%$ of the country risk."

\begin{tabular}{|c|c|c|}
\hline & Ukraine & Source \\
\hline Nominal risk-free rate in USA & $5,50 \%$ & 30-year US bonds \\
\hline Long-term inflation in USA & $3,00 \%$ & World Bank \\
\hline Real risk-free rate in USA $\left(\mathrm{R}_{\mathrm{F}}\right)$ & $2,50 \%$ & A \\
\hline $\begin{array}{l}\text { Country risk } \\
\text { Adjusted country risk (Crs) }\end{array}$ & $\begin{array}{l}13,50 \% \\
6,75 \%\end{array}$ & B Bloomberg (Sovereign bonds premium) \\
\hline Adjusted real risk-free rate & $9,4 \%$ & $C=(1+A)(1+B)-1$ \\
\hline Unlevered Beta (Bu) & 0,34 & D Bloomberg \\
\hline Market risk premium in USA & $5,00 \%$ & E Ibbotson \\
\hline US small size equity premium & $2,60 \%$ & F Ibbotson \\
\hline Specific risk Premium & $2,00 \%$ & $\mathrm{G}$ \\
\hline Required return to equity $(\mathrm{Ku})$ & $15,72 \%$ & $\mathrm{C}+\mathrm{DxE}+\mathrm{F}+\mathrm{G}$ \\
\hline
\end{tabular}

1.G.2. Including an odd illiquidity premium. Taken from an investment bank: " $\mathrm{Ku}$ is an estimate of the expectations of return for the shareholders taking into consideration only the business risk of the company. $\mathrm{Ku}$ is calculated as follows:

$$
\mathrm{Ku}=\mathrm{R}_{\mathrm{F}}+\mathrm{Crs}+\mathrm{Bu} \times\left[\left(\mathrm{Rm}-\mathrm{R}_{\mathrm{F}}\right)+\mathrm{Lr}\right]
$$

The Ukrainian risk-free rate $\left(\mathrm{R}_{\mathrm{F}}\right)$ is the USA risk-free rate of 4.59\% (10-year Gov. Bonds) minus a correction of 2.5\% for inflation (source: U.S. Treasury), because the cash flows are calculated in real terms $\left(\mathrm{R}_{\mathrm{F}}=4.59 \%-2.5 \%=2.09 \%\right)$. Then, we add a spread for country risk premium in Ukraine (Crs) of 7.5\%, based in the B- (sources: SetP, Fitch IBCA y Thomson). $R_{F}+$ Crs $=9.59 \%$.

\footnotetext{
${ }^{2}$ The company had insurance coverage up to $\$ 50$ millions.
} 
The market risk premium $\left(\mathrm{Rm}-\mathrm{R}_{\mathrm{F}}\right)$ is the European historical market risk premium of $5 \%$ calculated in the Millennium Book (source: ABN Amro y London Business School).

The illiquidity risk premium ( $\mathrm{Lr}$ ) is the additional premium observed for the small companies, usually considered as riskier. We consider the average small cap illiquidity discount of Détroyat Associés from January to March 2001 (3.42\%).

The unlevered beta is the average of the following sample:

\begin{tabular}{|l|c|c|c|c|c|}
\hline Diversified companies of seed oil & $\begin{array}{c}\text { Equity Beta } \\
\text { (Bloomberg) }\end{array}$ & Capitalization & $\begin{array}{c}\text { Net } \\
\text { debt }\end{array}$ & Tax rate & $\begin{array}{c}\text { Unlevered } \\
\text { beta }\end{array}$ \\
\hline Archer Daniels Midland & 0,50 & 7664 & 3933 & $35 \%$ & 0,37 \\
\hline Aarhus Oliefabrik A/S & 0,47 & 920 & 1461 & $36 \%$ & 0,23 \\
\hline Koipe SA & 0,25 & 350 & -133 & $35 \%$ & 0,33 \\
\hline Average & 0,41 & & \\
\hline
\end{tabular}

$\mathrm{Ku}=4,59 \%-2,5 \%+7,5 \%+0,31 \times[5 \%+3,42 \%]=12,2 \%$ in March 2001."

1.G.3. Including a small-cap premium equal for all companies. Damodaran (2002, page 207) says that the required return to equity for small companies should be calculated: "Ke $=R_{F}+$ $\beta \mathrm{P}_{\mathrm{M}}+\mathrm{SCP}$; being SCP $=$ Small cap premium $=2 \%$ because historically, the average return for the shareholders of small companies has been $2 \%$ higher than the average return for shareholders of the big companies."

\section{Errors when calculating or forecasting the expected cash flows}

\section{A. Wrong definition of the cash flows}

2. A.1. Forgetting the increase in working capital requirements when calculating cash flows. An example is error 1 in Appendix 2.

2. A.2. Considering an increase in the company's cash position or financial investments as an equity cash flow. Examples of this error may be found in many valuations; and also in Damodaran (2001, page 211), who argues that "when valuing a firm, you should add the value of cash balances and near-cash investments to the value of operating assets." In several valuations of Internet companies, the analysts calculate the present values of expected cash flows and add the company's cash, even though it is well known that the company is not going to distribute it in the foreseeable future.

It is wrong to add all the cash because:

1. The company needs some cash to continue its operations, and

2. The company is not expected to distribute the cash immediately.

It will be correct to add the cash only if:

- The interest received on the cash was equal to the interest paid on the debt, or

- The cash is due be distributed immediately, or 
- The cost of debt used to calculate the WACC was the weighted average of the cost of debt and the interest received on the cash holdings. In this case, the debt used to calculate the debt to equity ratio must be debt minus cash. Increases in cash must then be included in "Investments in working capital."

The value of the excess cash (cash above and beyond the minimum cash needed to continue operations) is lower than its book value if the interest received on the cash is lower than the interest paid on the debt. The company increases its value by distributing excess cash to the shareholders or by using it to reduce its debt, rather than keeping it.

2. A.3. Errors in the calculation of the taxes that affect the FCF. Using the taxes paid (in \$ amount) by the levered company. Some valuers use the statutory tax rate, or a tax rate other than the tax rate of the levered company, to calculate the FCF. Fernández (2002, page 501) claims that the correct tax rate for calculating the FCF is the tax rate of the levered company.

2. A.4. Expected equity cash flows are not equal to expected dividends plus other payments to shareholders (share repurchases, etc.). In several valuation reports, the valuer computes the present value of positive equity cash flows in years when the company does not distribute anything to shareholders. Also, Stowe, Robinson, Pinto, and McLeavey (2002) say that "Generally, Equity Cash Flow and dividends will differ. Equity Cash Flow recognizes value as the cash flow available to stockholders even if it is not paid out." Obviously, that is not correct, unless we assume that the amounts not paid out are reinvested and obtain a return equal to Ke (the required return to equity).

2. A.5. Considering net income as a cash flow. Fernández (2002, page 178) points out that net income is equal to the equity cash flow only in a no-growth perpetuity (a constant P\&L and constant balance sheet company).

2. A.6. Considering net income plus depreciation as a cash flow. Example taken from a valuation performed by an institution: "The sum of the net income plus depreciation is the rent (cash flow) generated by the company." Then, the valuer concluded that the equity value was the net present value of this "rent".

2. A.7. Considering that the NOPAT (Net Operating Profit After Taxes) is a cash flow. Example from Haight (2005, page 26): "NOPAT is basically EBIT adjusted for taxes... Thus, NOPAT represents the funds available to pay for both the debt and equity capital used by the organization."

\section{B. Errors when valuing seasonal companies}

2. B.1. Wrong treatment of seasonal working capital requirements. Fernández (2003) provides a valuation of a company in which the seasonality is due to purchases of raw materials: the equity value of this company calculated using annual data without making the necessary adjustments understates the true value by $45 \%$ if the valuation is done at the end of December, and overstates the true value by 38\% if the valuation is done at the end of November. The error due to adjusting only by using average debt and average working capital requirements ranges from $-17.9 \%$ to $8.5 \%$.

2. B.2. Wrong treatment of inventories that are cash equivalents. Fernández (2003) shows that when inventories are a liquid commodity such as grain or seeds, it is not correct to consider all of them as working capital requirements. Excess inventories financed with debt are equivalent to a set of futures contracts: not considering them as such leads us to undervalue the company. 
2. B.3. Wrong treatment of seasonal debt. Fernández (2003) shows that the error due to using annual data instead of monthly data when there is seasonal debt is enormous. It also shows that adjusting by using average debt reduces the error, but the error is still considerable.

\section{C. Errors due to not projecting the balance sheets}

2. C.1. Forgetting balance sheet accounts that affect the cash flows. In a balance sheet,

$$
\mathrm{WCR}+\mathrm{NFA}=\mathrm{D}+\mathrm{Ebv},
$$

where WCR = Working Capital Requirements; NFA = Net Fixed Assets; D = Book value of debt; $\mathrm{Ebv}=$ Book value of equity. It also holds that

$$
\Delta \mathrm{WCR}+\Delta \mathrm{NFA}=\Delta \mathrm{D}+\Delta \mathrm{Ebv} .
$$

Many valuations are wrong because the valuer did not project the balance sheets, and the increase in assets ( $\triangle \mathrm{WCR}+\triangle \mathrm{NFA}$, which appear in the cash flow calculation) does not match the assumed increase in debt plus the assumed increase in the book value of equity.

2. C.2. Considering an asset revaluation as a cash flow. In countries with high inflation, companies are permitted to revalue their fixed assets (and their net worth). But this is merely an accounting appreciation, not a cash outflow (although the fixed assets increase) nor a cash inflow (although the net worth increases).

2. C.3. Interest payments are not equal to debt times cost of debt. In several valuations, this simple relationship did not hold.

2. D. Exaggerated optimism when forecasting the cash flows. Two examples are error 5 in Appendix 2 and the following lines extracted from a valuation report about Enron Corp., produced by a recognized investment bank on July 12, 2001, when the share price was $\$ 49$.

"We view Enron as one of the best companies in the economy. There are still several misconceptions about Enron that mask the company's strong fundamentals. We therefore hosted an investor conference call on June 27 to clarify Enron's growth prospects and answer investors' questions.

"We expect Enron shares to rebound sharply in the coming months. We believe that Enron shares have found their lows and will recover significantly as investor confidence in the company returns and as misconceptions about Enron dissipate. We strongly reiterate our Buy rating on the stock with a $\$ 68$ price target over the next 12 months.

"Enron is a world-class company, in our view. We view Enron as one of the best companies in the economy, let alone among our group of diversified natural gas companies. We are confident in the company's ability to grow earnings 25\% annually for the next five to ten years, despite its already large base. We believe that Enron investors have the unique opportunity to invest in a high growth company with improving fundamentals.

"We strongly reiterate our Buy rating on the stock with a $\$ 68$ price target over the next 12 months. 
Enron earning model, 1994-2005E. US\$ millions except per-share data

\begin{tabular}{|l|l|l|l|l|l|l|l|l|l|l|l|l|}
\hline & 1994 & 1995 & 1996 & 1997 & 1998 & 1999 & 2000 & $2001 \mathrm{E}$ & $2002 \mathrm{E}$ & $2003 \mathrm{E}$ & $2004 \mathrm{E}$ & $2005 \mathrm{E}$ \\
\hline Net income & 438 & 504 & 568 & 88 & 686 & 827 & 896 & 1,563 & 1,939 & 2,536 & 3,348 & 4,376 \\
\hline Adjusted EPS & 0.83 & 0.91 & 0.91 & 0.87 & 1.00 & 1.18 & 1.47 & 1.85 & 2.25 & 2.75 & 3.52 & 4.47 \\
\hline Dividends per share & 0.38 & 0.41 & 0.43 & 0.46 & 0.48 & 0.50 & 0.50 & 0.50 & 0.50 & 0.50 & 0.50 & 0.50 \\
\hline Book value per share & 5.15 & 5.65 & 6.64 & 9.27 & 9.95 & 12.28 & 13.94 & 15.47 & 17.99 & 21.02 & 24.79 & 29.47 \\
\hline
\end{tabular}

"We recently raised our 2001 EPS estimate \$0.05 to \$1.85 and established a well-aboveconsensus 2002 estimate of $\$ 2.25$. We are confident in the company's ability to grow earnings $25 \%$ annually for the next five to ten years, despite its already large base."

It is well known what happened to Enron's share price after the date of this report.

\section{Errors in the calculation of the residual value}

3. A. Using inconsistent cash flow to calculate the value of a perpetuity. An example is the valuation of a manufacturing company performed by a financial consulting firm (see Table 9), which shows a valuation performed by discounting expected free cash flows at the WACC rate of $12 \%$. Lines 1 to 5 contain the calculation of the free cash flows. NOPAT (Net Operating Profit After Taxes) does not include interest expenses. The residual value in 2007 is calculated assuming a residual growth of 2.5\%:

Residual value in $2007=12,699=1,177 \times 1.025 /(0.12-0.025)$.

\section{Table 9}

Valuation of a manufacturing company performed by a financial consulting firm

\begin{tabular}{|c|c|c|c|c|c|c|}
\hline Line & \$million & 2003 & 2004 & 2005 & 2006 & 2007 \\
\hline 1 & Net Operating Profit After Taxes & 500 & 522 & 533 & 574 & 616 \\
\hline 2 & Depreciation & 1,125 & 1,197 & 1,270 & 1,306 & 1,342 \\
\hline 3 & Capital expenditures & $-1,445$ & -722 & -722 & -361 & -361 \\
\hline 4 & Investment in working capital & 203 & -450 & -314 & -399 & -420 \\
\hline 5 & Free cash flow & 383 & 547 & 767 & 1,120 & 1,177 \\
\hline 6 & \multicolumn{5}{|c|}{ Residual value in 2007 (WACC $12 \%$ and residual arowth $2.5 \%$ ) } & 12,699 \\
\hline
\end{tabular}

Present value in 2002 of free cash flows (WACC =12\%)

\begin{tabular}{|l|l|c|}
\hline 7 & $2003-2007$ & 2,704 \\
\hline 8 & Residual value in 2007 & 7,206 \\
\hline 9 & Total EV (Enterprise Value) & 9,909 \\
\hline 10 & Plus cash & 280 \\
\hline 11 & Minus debt & $-3,628$ \\
\hline 12 & Equity value & 6,561 \\
\hline
\end{tabular}

The enterprise value (line 9) is the sum of the present value of the free cash flows 2003-2007 (line 7) plus the present value of the terminal value (line 8). Adding cash (line 10) and subtracting debt value (line 11), the financial consulting firm calculates the equity value (line 12) as $\$ 6.561$ million. It sounds reasonable, but the valuation contains two errors: 
1. It is inconsistent to use the FCF of 2007 to calculate the residual value. The reason for this is that in 2007 the forecast capital expenditures (361) are smaller than the forecast depreciation $(1,342)$. It is wrong to assume that this will happen in the future indefinitely: net fixed assets would be negative by 2010 !

2. The normative 2007 FCF used to calculate the residual value should be $\$ 196$ million (assuming capital expenditures equal to depreciation) or less (if we assume that the net fixed assets also grow at 2.5\%). Correcting this error in the valuation, Table 3 shows that the equity value is reduced to $\$ 556$ million (instead of $\$ 6,561$ million).

\section{Table 10}

Valuation of the manufacturing company in Table 9 adjusting the normative free cash flow and the residual value

\begin{tabular}{|r|l|c|}
\cline { 2 - 3 } \multicolumn{1}{c|}{} & Normative 2007 FCF & $\mathbf{1 9 6}$ \\
\hline 6 & Residual value in 2007 & $\mathbf{2 , 1 1 5}$ \\
\hline \multicolumn{2}{|c|}{ Present value in 2002 of free cash flows: } \\
\hline 7 & $2003-2007$ & 2,704 \\
\hline 8 & Residual value in 2007 & $\mathbf{1 , 2 0 0}$ \\
\hline 9 & Total EV (Enterprise Value) & $3,9025 /(0.12-0.025)$ \\
\hline 10 & Plus cash & 280 \\
\hline 11 & Minus debt & $-3,628$ \\
\hline 12 & Equity value & $\mathbf{5 5 6}$ \\
\hline
\end{tabular}

Of course, in a given year or in several years, capital expenditures may actually be lower than depreciation, but it is not consistent to take this as the normative cash flow for calculating the residual value as a growing perpetuity.

3. B. The debt-to-equity ratio used to calculate the WACC for discounting the perpetuity is different from the debt-to-equity ratio resulting from the valuation. This error is commonly made in many valuations and is also found in the valuation in section 1. D.2.

3. C. Using ad hoc formulas that have no economic meaning. An example is error 4 in Appendix 2.

3. D. Using arithmetic averages instead of geometric averages to assess growth. An example is given in Table 11, which shows the past evolution of the EBITDA of a manufacturing company operating in a mature industry. The investment bank that performed the valuation used this table as a justification for a forecast average annual increase of EBITDA of $6 \%$. It is obvious that the geometric average is a much better indicator of average growth in the past.

\section{Table 11}

Arithmetic vs. geometric growth

\begin{tabular}{|l|c|c|c|c|c|c|c|c|}
\cline { 2 - 9 } \multicolumn{1}{c|}{} & 1995 & 1996 & 1997 & 1998 & 1999 & 2000 & 2001 & 2002 \\
\hline EBITDA & 127 & 132 & 149 & 91 & 150 & 132 & 146 & 147 \\
\hline Annual growth & & $3.9 \%$ & $12.9 \%$ & $-38.9 \%$ & $64.8 \%$ & $-12.0 \%$ & $10.6 \%$ & $0.7 \%$ \\
\hline Arithmetic average 1995-2002 & $6.0 \%$ & & &
\end{tabular}


3. E. Calculating the residual value using the wrong formula. When the residual value is calculated as a growing perpetuity, the correct formula is $R V_{t}=C_{t+1} /(K-g) \cdot R V_{t}$ is the residual value in year $t . \mathrm{CF}_{\mathrm{t}+1}$ is the cash flow of the following year. $\mathrm{K}$ is the appropriate discount rate, and $g$ is the expected growth of the cash flows. But many valuations use the following incorrect formulae:

$$
\begin{aligned}
& \mathrm{RV}_{\mathrm{t}}=\mathrm{CF}_{\mathrm{t}} /(\mathrm{K}-\mathrm{g}) \\
& \mathrm{RV}_{\mathrm{t}}=\mathrm{CF}_{\mathrm{t}+1}(1+\mathrm{g}) /(\mathrm{K}-\mathrm{g})
\end{aligned}
$$

\section{F. Assuming that a perpetuity starts a year before it really starts}

\section{Inconsistencies and conceptual errors}

\section{A. Conceptual errors around free cash flow and equity cash flow}

4. A.1. Considering the cash in the company as an equity cash flow when the company is not going to distribute it. An example of this was given in section 1.

4. A.2. Using real cash flows and nominal discount rates, or vice versa. An example is the valuation in section 1. D.1, which also has another error: the projected FCF are given in real terms, that is, excluding inflation (which is why free cash flows are constant from 2007-2009), while $\mathrm{Ku}(14.6 \%)$ is calculated in nominal terms, that is, including inflation.

For a correct valuation, the cash flows and the discount rate used must be consistent. This means that:

- Cash flows in real terms must be discounted with real discount rates, and

- Cash flows in nominal terms must be discounted with nominal discount rates.

The correct way is to either increase cash flows by inflation or deduct inflation from nominal discount rates. In fact, for real (constant) cash flows, such as those used in this valuation, we must use real WACC and real Ku:

$$
\begin{aligned}
& \text { Real WACC }=(1+\text { Nominal WACC }) /(1+\text { expected inflation })-1 \\
& \text { Real } \mathrm{Ku}=(1+\text { Nominal } \mathrm{Ku}) /(1+\text { expected inflation })-1
\end{aligned}
$$

4. A.3. The free cash flow and the equity cash flow do not satisfy ECF $=F C F+\Delta D-$ Int (1-T). This equation represents the relationship between the equity cash flow and the free cash flow. It may be found in Fernández (2002, pages 42 and 401). In many valuation reports, given the FCF, the debt increase $(\Delta \mathrm{D})$, the interest payments (Int), and the effective tax rate (T), the calculated ECF bears no relation at all to the company's expected equity cash flows (dividends plus share repurchases). 


\section{B. Errors when using multiples}

4. B.1. Using the average of multiples extracted from transactions executed over a very long period of time. An investment bank produced this valuation in January 2003. "Table 12 shows the multiples of recent transactions. We use the median of these multiples (6.8), as the median eliminates extremes."

\section{Table 12}

Transaction multiples in the oil business

\begin{tabular}{|l|l|c|c|}
\hline Acquirer/Target & Date & EV/EBITDA & EV/EBIT \\
\hline Bunge/Cereol & November 2002 & $6.3 x$ & $9.6 x$ \\
\hline Cargill/Cerestar & October 2001 & $12.1 \mathrm{x}$ & na \\
\hline Land O'Lakes/Purina Mills & June 2001 & $4.0 \mathrm{x}$ & $8.2 \mathrm{x}$ \\
\hline Primor Inversiones/Mavesa & January 2001 & $7.5 \mathrm{x}$ & $10.3 \mathrm{x}$ \\
\hline Corn Product International/Arcancia CPC & October 1998 & $7.3 \mathrm{x}$ & na \\
\hline Eridania Béghin-Say/American Maize products & February 1995 & $5.5 \mathrm{x}$ & $8.3 \mathrm{x}$ \\
\cline { 1 - 3 } & Average & $7.1 \mathrm{x}$ & $9.1 \mathrm{x}$ \\
& Median & $6.8 \mathrm{x}$ & $9.0 \mathrm{x}$ \\
\cline { 2 - 4 }
\end{tabular}

\section{Errors}

1. The multiples come from a very long period of time: from February 1995 to November 2002.

2. Dispersion of the multiples. The EV/EBITDA ranges between 4 and 12.1. Why should 6.8 (the median) be a reasonable multiple?

4. B.2. Using the average of transactions multiples that have a wide dispersion. An example is Table 12 .

4. B.3. Using multiples in a way that is inconsistent with their definition. An example is Table 13, which shows a valuation performed by a well known investment bank using the price-earnings ratio.

\section{Table 13}

Valuation using the price-earnings ratio.

\begin{tabular}{|c|l|c|c|}
\hline 1 & Expected net income of next year & 28.6 & \$ millions \\
\hline \multicolumn{2}{|c|}{ Valuation using PER } & Minimum & Maximum \\
\hline 2 & Assumed PER & 9.0 & 10.0 \\
\hline 3 & PER $x$ net income & 257.4 & 286.0 \\
\hline 4 & Plus: excess cash & 93.1 & 93.1 \\
\hline 5 & Minus: Financial debt & 115.6 & 115.6 \\
\hline 6 & Minus: Retirement commitments & 34.5 & 34.5 \\
\hline 7 & Equity value & 200.4 & 229.0 \\
\hline
\end{tabular}

Error. The price-earnings ratio is equal to the equity value divided by net income. It is not correct to deduct the debt (line 5). The correct equity value (according to the assumptions) 
should be 115.6 million higher than line 7. Adding the excess cash (line 4) is correct in this case because the buyer planned to distribute the excess cash immediately to the shareholders.

4. B.4. Using a multiple from an extraordinary transaction. An example is the following valuation performed by a consulting firm for an arbitrage.

Table 14 shows the balance sheets and P\&L of Telecosin.

\section{Table 14}

Balance sheets and P\&L of Telecosin, 1995-2000

\begin{tabular}{|c|c|c|c|c|c|c|}
\hline (Thousand euros) & 1995 & 1996 & 1997 & 1998 & 1999 & 2000 \\
\hline Sales & 336 & 768 & 1,009 & 1,848 & 2,746 & 6,815 \\
\hline Net income & 15 & 8 & 11 & 98 & 156 & 87 \\
\hline Dividends & 0 & 0 & 0 & 0 & 0 & 0 \\
\hline
\end{tabular}

\begin{tabular}{|l|r|r|r|r|r|r|}
\hline Cash and banks & 33 & 13 & 53 & 426 & 421 & 82 \\
Accounts receivable & 119 & 201 & 211 & 635 & 779 & 3,372 \\
Inventories & 0 & 73 & 20 & 42 & 150 & 141 \\
Net fixed assets & 59 & 53 & 50 & 158 & 235 & 804 \\
\hline TOTAL ASSETS & 212 & 340 & 334 & 1,261 & 1,586 & 4,400 \\
\hline
\end{tabular}

\begin{tabular}{|l|r|r|r|r|r|r|}
\hline Short-term financial debt & 0 & 0 & 2 & 2 & 0 & 1,124 \\
Trade creditors & 100 & 233 & 102 & 212 & 204 & 1,619 \\
Other creditors & 47 & 36 & 146 & 340 & 558 & 798 \\
Long-term bank debt & 0 & 0 & 0 & 405 & 367 & 314 \\
Shareholders' equity & 64 & 72 & 83 & 301 & 457 & 545 \\
\hline TOTAL LIABILITIES & 212 & 340 & 334 & 1,261 & 1,586 & 4,400 \\
\hline
\end{tabular}

"The legitimacy of the comparable transactions method is based on the fact that financial analysts working for merchant banks, consulting firms and financial companies for valuing companies like Telecosin widely and predominantly use this method and the revenue parameter.

"In September last year a group of investors consisting of Dresdner Kleinwort Benson, MCH and Sibec acquired 20\% of the company IP Systems for 3.6 million euros. This implies that 100\% of the company was valued at 18 million euros.

"IP Systems has many features in common with Telecosin, making it a suitable point of comparison for determining the value of Telecosin. There are, however, two differences in Telecosin's favor that need to be mentioned: long experience in the market (which implies more consolidated goodwill and greater recognition by customers), and a significantly larger workforce. The following table offers a comparison of the two companies:

\begin{tabular}{|l|l|l|}
\cline { 2 - 3 } \multicolumn{1}{c|}{} & IP SYSTEMS & Telecosin \\
\hline Turnover 99 & 0.9 million euros $(1$ month) & 2.75 million euros \\
\hline Turnover 2000 & 10.4 million euros & 6.81 million euros \\
\hline Workforce & 63 people & 110 people \\
\hline Founded in & 1999 & 1994 \\
\hline
\end{tabular}


In 1999 IP Systems had a turnover of 0.9 million euros. However, the company had only started trading in November. If we extrapolate this turnover to the year as a whole, we get an annual turnover of 5.4 million. Therefore, the growth in IP System's turnover in the period 1999-2000 is $90 \%$, lower than that of Telecosin in the same period (146\%).

The IP Systems investors valued the company with reference to the sales figure for the current year (2000), using a sales multiple of 1.7. If this same multiple (1.7) is applied to Telecosin's minimum forecast sales for 2001 (16.8 million euros), the value of the shares of the company in December 2000 is 28.6 million.

\section{Decision of the Court of Arbitration}

"A party has presented a valuation based on what is known as the comparable transactions method. Some securities firms and investment banks had been using this method for a period of approximately two years (between 1998 and 2000). There was a clear reason for using it: it was impossible to explain the exorbitant prices paid for many new economy firms using the methods in general use up until then. The comparable transactions method never had any theoretical underpinnings. And certainly, after the summer or autumn of 2000 it was totally discredited. This method is therefore not worth considering.

"We are left, therefore, with the discounted cash flow method, which is the most widely accepted method of firm valuation, and the one that the Panel of Arbitrators considers most appropriate in this case. We value the shares of Telecosin at 2.4 million euros."

4. B.5. Using ad hoc valuation multiples that conflict with common sense. An example is the valuation of Terra's shares performed by a Euro-American bank in April 2000 (see Table 15), when Terra's share price was 73.8 euros. As the valuation given by Table 15 is 104 euros per share, the bank advised its customers to buy Terra shares.

The valuation is based on the 15 largest Internet companies in the USA. The first column gives the price per share, the second column the number of shares outstanding, and the third column the companies' capitalization in million dollars. When the net debt is added to the capitalization, what the bank calls enterprise value (EV) is obtained. Thus, the sum of the enterprise values of the 15 largest Internet companies in USA was 278.145 billion dollars. The Euro American bank's analyst then divided this quantity by the number of inhabitants in the U.S., which he estimated to be 273 million, obtaining the EV per capita in the U.S.: 1,019 dollars.

At the bottom of Table 15, the analyst divided Terra's market into three geographical areas: Spain, Hispanic America (U.S. citizens who are Spanish speakers) and Latin America. Column [1] shows the gross national product per capita in each of the three geographical areas, and column [2] shows the percentage they represent with respect to the gross national product per capita in USA $(\$ 32,328)$. Column [3] is the result obtained by multiplying the EV per capita in the U.S. (1,019 dollars) by the ratio between the gross national product per capita in each of the three geographical areas and the U.S. gross national product per capita (column [2]). He then multiplied column [3] by the number of inhabitants in each geographical area (column [4]) and by Terra's estimated market share in each of these markets (column [5]), to obtain Terra's value in each of these geographical areas (column [6]). Adding the three amounts in column [6], he arrived at the value for Terra: 27.117 billion dollars. After subtracting the net debt from this amount, he obtained Terra's implicit capitalization: 27.642 billion dollars. By dividing this quantity by the number of Terra shares (280 million) and by the euro exchange rate, the analyst obtained the value of the Terra share: 104 euros per share. 
Doesn't this valuation seem surprising to the reader? We suggest another way of getting the figure of 104 dollars per share: The value of the Terra share is twice the age of Manolo Gómez's mother-in-law, who is 52. We chose Manolo because he lives near Terra's corporate headquarters. Of course, this valuation is absurd, but it has as much rigor as that given in Table 15. As the saying goes, "the blind man dreamt that he was able to see, and he dreamt what he wanted to see." ${ }^{3}$

Terra traded at 11 euros at the end of 2000, at 9 euros at the end of 2001, and was trading between 4 and 5.4 euros in the first six months of 2003.

\section{Table 15}

Valuation of Terra performed by a Euro-American bank on 7 April 2000

\begin{tabular}{|lcr|r|r|r|}
\cline { 2 - 6 } \multicolumn{1}{c|}{} & $\begin{array}{c}\text { Price per } \\
\text { share (\$) }\end{array}$ & Million shares & $\begin{array}{c}\text { Capitalization } \\
\text { (\$ millions) }\end{array}$ & Net debt & $\begin{array}{c}\text { EV (enterprise } \\
\text { value) }\end{array}$ \\
\hline AOL & 65.0 & 2,282 & 148,315 & $-1,472$ & 146,843 \\
Yahoo! & 158.0 & 526 & 83,184 & $-1,208$ & 81,976 \\
Lycos & 61,5 & 110 & 6,760 & -618 & 6,142 \\
Excite@Home & 30,0 & 352 & 10,559 & 302 & 10,861 \\
Go Networks & 19,0 & 165 & 3,133 & 349 & 3,482 \\
NBC Interactive & 38,5 & 32 & 1,223 & 259 & 1,482 \\
About.com & 65,0 & 17 & 1,075 & -176 & 899 \\
The Go2Net & 71,4 & 31 & 2,182 & 214 & 2,396 \\
Ask Jeeves & 59,0 & 35 & 2,062 & -166 & 1,896 \\
LookSmart & 38,0 & 88 & 3,340 & -97 & 3,243 \\
Juno & 13,8 & 39 & 531 & -89 & 442 \\
Infospace & 65,5 & 217 & 14,186 & -89 & 14,097 \\
GoTo.com & 43,0 & 49 & 2,107 & -104 & 2,003 \\
Earthink & 18,0 & 138 & 2,489 & -206 & 2,283 \\
TheGlobe.com & 5,0 & 30 & 152 & -52 & 100 \\
\hline Sum of the 15 largest information hubs in USA & $\mathbf{2 8 1 , 2 9 8}$ & $-\mathbf{3 , 1 5 3}$ & $\mathbf{2 7 8 , 1 4 5}$ \\
\hline
\end{tabular}

\begin{tabular}{|ll|}
\hline No. inhabitants (million) & 273 \\
EV per capita (US\$) & 1,019 \\
GNP per capita in the US (US\$) & 32,328
\end{tabular}

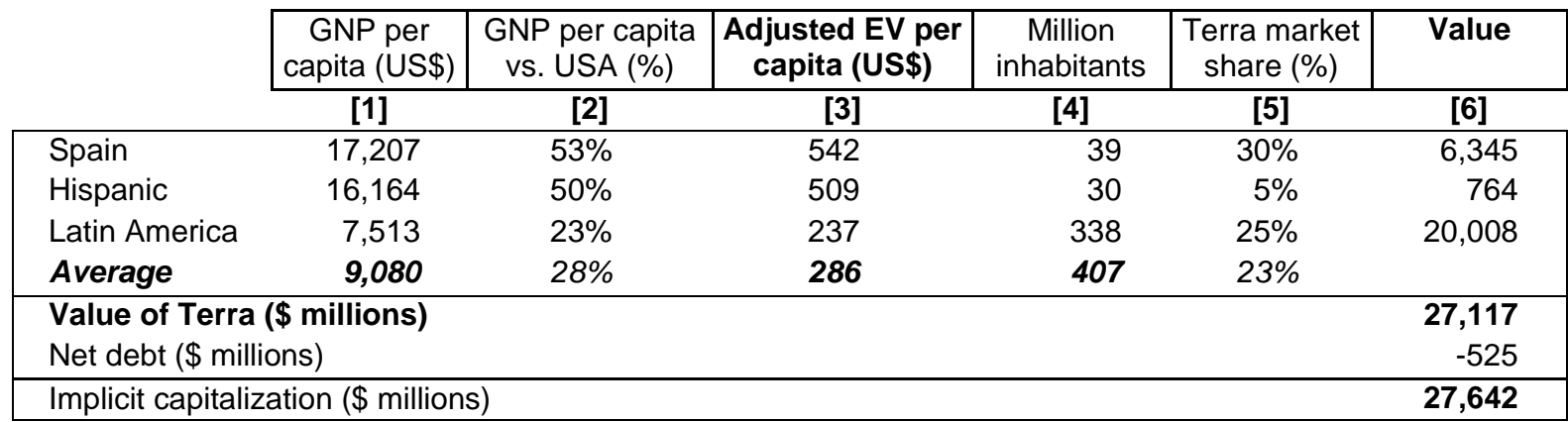

Million shares: $280 \quad$ Dollar/euro exchange rate: 0.94875

Price per share (euros)

104

\footnotetext{
${ }^{3}$ Other valuations of Internet companies using esoteric multiples may be seen in Fernández (2002), chapter 12.
} 
4. B.6. Using multiples without using common sense. Example: In May 2001, during an arbitrage taking place in Europe, a valuation expert was asked: "Three companies A, B, and C have similar sales. We do not know their net income. The Book values of equity are as follows: A: €0,7 million; B: €6 million; C: €6 million. Questions:

1.- Would you use a sales multiple to value those companies? Answer: Yes.

2.- Would you use the same sales multiple to value the three companies? Answer: Yes, if the sales evolution has been similar, I would use the same multiple.

3.- If the evolution of the sales of the three companies has been similar, do the three companies have about the same value? Answer: Yes, the value of the three companies is the same."

\section{C. Time inconsistencies}

4. C.1. Assuming that the equity value will be constant in the future. Example taken from an analyst's valuation report: "As we do not know the evolution of the equity value of the company, a good approximation is to assume that the equity value will remain constant in the following five years." That is not correct. Fernández (2002, pages 401 and 497) shows that the relationship between the equity value of different years is: $E_{t}=E_{t-1}\left(1+K_{t}\right)-E_{C F}$. Note that the equity value is constant $\left(\mathrm{E}_{\mathrm{t}}=\mathrm{E}_{\mathrm{t}-1}\right)$ only if $\mathrm{ECF}_{\mathrm{t}}=\mathrm{E}_{\mathrm{t}-1} \mathrm{Ke}_{\mathrm{t}}$. That only happens in no-growth perpetuities.

4. C.2. The Equity value or the Enterprise Value does not satisfy the time consistency formulae. Fernández (2002, page 401) shows that the relationship between the enterprise value of different years is: $\mathrm{E}_{\mathrm{t}}+\mathrm{D}_{\mathrm{t}}=\left(\mathrm{E}_{\mathrm{t}-1}+\mathrm{D}_{\mathrm{t}-1}\right)(1+\mathrm{WACC} \mathrm{t})-\mathrm{FCF}_{\mathrm{t}}$.

\section{D. Other conceptual errors}

4. D.1. Not considering cash flows resulting from future investments. An example could be the valuation of Oleina Holding, a leading edible oil company in the Ukraine, with strong volume and brand recognition also in Russia. The company was operating almost at full capacity and had plans to invest in a new plant in Russia.

Example taken from an investment bank: "From a methodological viewpoint, if this project had to be taken into account, its net present value should be assumed to be nil. The most reasonable approach would be to assume that the investment is expected to deliver a return that is equal to financial market expectations, which implies a net present value equal to zero."

Example taken from a business school professor, acting as expert witness in an arbitrage: "By taking into account a future Russian plant project in the valuation, the seller of the shares would benefit from the profits generated by this new project without incurring the related risks, as he would anyway not take part in the future investment."

4. D.2. Considering that a change in economic conditions invalidates signed contracts. A European bank bought a securities company on February 16, 2001. The European bank bought $80 \%$ of the shares and gave the current owners a put on the remaining $20 \%$ of the shares with an exercise price of 54 million euros (same per-share price as the transaction). The current owners tried to exercise the put in May 2002, but the European bank refused, arguing that: "As, due to specific extraordinary circumstances, the situation of the financial markets and of the world economy in May 2002 was a lot worse than on 16 February 2001, we have no obligation to accept the exercise of the put at the agreed exercise price. The unforeseen recession was 
aggravated by the shock of 11 September 2001, which had both short and medium-term effects, insofar as stock market behavior over the following twelve months was unfavorable and highly volatile." The European bank had a new valuation of the shares of the securities company on May 2002 that argued that the price of the shares had fallen 86.3\% since February 2001.

\section{Table 16}

The effect of September 11, 2001 on four stock indexes (S\&P 500, NASDAQ, EURO STOXX 50, and FTSE 100) was short-lived.

\begin{tabular}{|c|c|c|c|c|c|}
\hline & S\&P 500 & NASDAQ & EURO STOXX 50 & FTSE 100 & \\
\hline $10 / 09 / 01$ & 1092.5 & 1695.4 & 3440.7 & 5033.7 & \\
\hline $11 / 09 / 01$ & 1092.5 & 1695.4 & 3220.3 & 4746.0 & September 11, 2001 \\
\hline 12/09/01 & 1092.5 & 1695.4 & 3260.9 & 4882.1 & \\
\hline $13 / 09 / 01$ & 1092.5 & 1695.4 & 3293.8 & 4943.6 & \\
\hline 14/09/01 & 1092.5 & 1695.4 & 3091.2 & 4755.8 & \\
\hline $17 / 09 / 01$ & 1038.8 & 1579.6 & 3205.0 & 4898.9 & \\
\hline 18/09/01 & 1032.7 & 1555.1 & 3189.9 & 4848.7 & \\
\hline 19/09/01 & 1016.1 & 1527.8 & 3105.1 & 4721.7 & \\
\hline $20 / 09 / 01$ & 984.5 & 1470.9 & 2967.9 & 4556.9 & \\
\hline $21 / 09 / 01$ & 965.8 & 1423.2 & 2877.7 & 4433.7 & Lowest level after September 11 \\
\hline $10 / 10 / 01$ & 1081.0 & 1626.3 & 3468.3 & 5153.1 & Eurostoxx higher than on September 10 \\
\hline $11 / 10 / 01$ & 1097.4 & 1701.5 & 3510.6 & 5164.9 & FTSE 100 higher than on September 10 \\
\hline $15 / 10 / 01$ & 1090.0 & 1696.3 & 3393.6 & 5067.3 & NASDAQ higher than on September 10 \\
\hline $16 / 10 / 01$ & 1097.5 & 1722.1 & 3455.3 & 5082.6 & S\&P 500 higher than on September 10 \\
\hline $26 / 10 / 01$ & 1104.6 & 1769.0 & 3611.9 & 5188.7 & \\
\hline
\end{tabular}

Source: Thomson Financial DataStream.

Contracts are signed to be fulfilled. On top of that, there are no grounds for the claim that stock market volatility increased significantly after 11 September 2001. By March 2002 the volatility of the main American indexes was similar to what it had been before September 11. Consequently, the effect of September 11 did not cause a permanent increase in volatility.

The effect of September 11 on prices was also short-lived. Table 16 shows what a short time the effect of September 11 on the S\&P 500, the NASDAQ and other world stock market indexes lasted. It is quite clear that the effect of September 11 did not lead to a permanent increase in volatility or a permanent decrease in prices. Consequently, it cannot be appropriate to say that the market risk increased as a result of September 11.

4. D.3. Considering that the value of debt is equal to its book value, when they are different. A common assumption in valuations is to consider that the value of debt (D) is equal to its book value $(\mathrm{N})$. However, there are circumstances in which this assumption is not reasonable. For example, if a company has long-term fixed rate debt and interest rates have increased (decreased), the debt value (D) will be lower (higher) than its book value (N).

4. D.4. Not using the correct formulae when the value of debt (D) is not equal to its book value (N). Fernández (2002, page 416) shows that the expression for the WACC, when the value of debt (D) is not equal to its book value (N), is WACC $=(\mathrm{E} \mathrm{Ke}+\mathrm{D} \mathrm{Kd}-\mathrm{N} \mathrm{r} \mathrm{T}) /(\mathrm{E}+\mathrm{D}) . \mathrm{Kd}$ is the required return to debt and $r$ is the cost of debt.

4. D.5. Considering that the book value of the shares is a good proxy for their market value. Example taken from a valuation by a well-known professor of the shares of El Corte Inglés on 26/12/2005, on the basis of their book value: "We consider that the best and most trustworthy 
criteria in order to value the shares of El Corte Inglés is based on the value of its shareholder's equity given by its consolidated balance sheet."

Further on, the argument goes: "the following table sums up the corresponding values to the equity shareholders' funds according to the balance sheet of the El Corte Inglés Company and according to the consolidated balance sheet of the group, both closed the $28^{\text {th }}$ of December of 2005."

“El Corte Inglés” Equity Shareholders’ Funds (thousands euros)

\begin{tabular}{|l|c|}
\hline & Consolidated Group \\
\hline Equity Capital & 446.292 \\
\hline Reserves & 5.497 .727 \\
\hline Equity shareholders' funds $(74.382 .000$ shares) & 5.944 .019 \\
\hline Book value of a share with $6 €$ as nominal & $79,91 €$ \\
\hline
\end{tabular}

Later on, another professor called this valuation: "a sound diagnosis" and backed his colleague's valuation by stating: "Actually, the previous report, which follows accurately the Technical Auditing Normative, chose one of the methods approved by the normative (the one based on net assets) and based its calculations on the annual accounts of El Corte Inglés, as they are a set of public and verified data, backed by a favorable auditing report, and he therefore proceeded to a valuation on these grounds."

4. D.6. Including the value of real options that have no economic meaning. An example: Table 17 contains the net present value calculation of a project for a new plant in Brazil for a supplier of automotive interior systems to most of the major car assemblers. Initial outlays amounted to nearly $\$ 38$ million. The project involved supplying components for 500,000 cars the first year and 850,000 cars the following years. The net present value of the project (given the cost of the new plant and the expected free cash flows), using a WACC of 14.95\%, is negative: $-\$ 7.98$ million.

\section{Table 17}

Net present value calculation of a project for a new plant in Brazil. WACC $=14.95 \%$

\begin{tabular}{|c|c|c|c|c|c|c|c|}
\hline (\$ million) in nominal terms & 0 & 1 & 2 & 3 & 4 & 5 & Salvage value \\
\hline FCF & -37.9 & 3.5 & 12.6 & 10.7 & 8.5 & 7.1 & 3.8 \\
\hline
\end{tabular}

However, the valuer argued that the owner of the plant had additional options that were not included in the net present value calculation:

- Options that came from obtaining further supply contracts in the future during the life of the plant (growth options, valued as three European options with strike prices of $\$ 5.6$, $\$ 0.4$ and $\$ 0.085$ million).

- Option to renew initial supply contracts at their expiration date (prolongation option, valued as a European option with strike price of $\$ 42.7$ million). The salvage value of the project was neither the value of its contract renewal nor the liquidation price of its assets, but the higher of the two.

- Flexibility options: possibility of adapting project costs to the evolution of sales. 
- Abandonment option: possibility of abandoning the investment prior to the end of its life (valued as an American put option on the future cash flows stream with strike price equal to its salvage value and maturity equal to the project's life).

Valuing the options and the project together, the valuer said that the expanded net present value (value of the plant taking into consideration the real options embedded in the investment) was as shown in Table 18. The valuer concluded: "Considering the real options together displays a significant positive expanded NPV for different assumptions about the future evolution of the state variable (number of cars produced and assembled in Brazil), and therefore validates the optimality of the investment decision."

\section{Table 18}

Expanded net present value of a project for a new plant in Brazil, as a function of the drift rate and of the volatility

\begin{tabular}{|l|c|c|c|}
\cline { 2 - 4 } \multicolumn{1}{c|}{ Volatility } & \multicolumn{3}{c|}{ Drift rate } \\
\cline { 2 - 4 } \multicolumn{1}{c|}{$\mathbf{0 \%}$} & $\mathbf{7 \%}$ & $\mathbf{1 5 \%}$ \\
\hline $\mathbf{7 \%}$ & 2.4 & 7.5 & 15.2 \\
\hline $\mathbf{1 3} \%$ & 2.5 & 7.6 & 15.2 \\
\hline $\mathbf{2 0} \%$ & 2.8 & 7.2 & 13.6 \\
\hline
\end{tabular}

Volatility is the standard deviation of the number of cars that are produced and assembled in Brazil.

Drift rate means the expected growth of the number of cars that are produced and assembled in Brazil.

Questions to the reader: Do the options belong to the company? Do you think that the specification of the options (which depend almost exclusively on the number of cars produced and assembled in Brazil) is a good description of them? Would you advise the company to invest in the project?

4. D.7. Considering shared options as one's own. An example would be to consider that the option of enlarging a washing machine factory in China is one's own. Obviously, such an option is shared by all the actual and potential manufacturers.

4. D.8. Forgetting to include the value of non-operating assets. Example taken from a valuation report: "We do not consider in our valuation the value of the shares that the company has in a traded telephone company because this investment is totally unrelated to the company's industrial and commercial activities." The value of a company's shares is the present value of the expected equity cash flows plus the current value of the non-operating assets.

4. D.9. Inconsistencies between discount rates and expected inflation. In a valuation report, the WACC (in nominal terms) used was 5.4\% and the expected inflation rate used to forecast the free cash flows was $6 \%$.

4. D.10. Valuing a holding company assuming permanent losses (without tax savings) in some companies and permanent profits in others. In a valuation report performed by an investment bank of a holding company that had two subsidiaries, the equity value of one subsidiary was put at $\$ 81$ million, and the equity value of the other, at $-\$ 33.9$. The taxes of the latter were forecast as zero because the company was assumed to have permanent losses.

4. D.11. Wrong concept of the optimal capital structure. Example taken from a valuation report: "The optimal capital structure is the one that maximizes the enterprise value (debt value 
plus equity value). In the context of the Adjusted Present Value, the enterprise value is equal to the value of the unlevered company plus the present value of tax shields. Since the value of the unlevered company is constant and unrelated to leverage, the optimal capital structure is the one that maximizes the present value of tax shields." More about the optimal capital structure may be found in chapter 18 of Fernández (2002).

4. D.12. In mature companies, assuming projected cash flows that are much higher than historical cash flows without any good reason. An example is error 5 in Appendix 2.

4. D.13. Assumptions about future sales, margins, etc., that are inconsistent with the economic environment, the industry outlook, or competitive analysis. Example taken from a valuation performed by a financial consultant of a platform company: "The following table presents the two extreme scenarios of the evolution of the sales of the company.

\begin{tabular}{|l|c|c|c|c|c|c|c|c|c|c|c|}
\cline { 2 - 11 } \multicolumn{1}{c|}{} & 2001 & 2002 & 2003 & 2004 & 2005 & 2006 & 2007 & 2008 & 2009 & 2010 & 2011 \\
\hline Optimistic & 2.7 & 3.5 & 4.2 & 5.1 & 6.2 & 7.4 & 9.0 & 10.5 & 12.1 & 13.6 & 15.0 \\
\hline Pessimistic & 2.7 & 3.4 & 4.1 & 4.9 & 5.7 & 6.8 & 8.0 & 9.2 & 10.5 & 11.6 & 12.5 \\
\hline
\end{tabular}

The expected inflation is $2 \% . "$

4. D.14. Considering that the ROE is the return to shareholders in non-traded companies. This is a fairly common and quite mistaken assumption. If ROE is a good approximation of the return to the shareholders of non-traded companies, it should be also a good approximation for traded companies. The following table shows that the ROE of General Electric has little to do with the return to its shareholders.

\begin{tabular}{|l|c|c|c|c|c|c|c|c|c|c|c|c|}
\hline General Electric & 1992 & 1993 & 1994 & 1995 & 1996 & 1997 & 1998 & 1999 & 2000 & 2001 & 2002 & Average \\
\hline Shareholder return & $14 \%$ & $26 \%$ & $1 \%$ & $44 \%$ & $40 \%$ & $51 \%$ & $42 \%$ & $53 \%$ & $-5 \%$ & $-15 \%$ & $-37 \%$ & $16 \%$ \\
\hline ROE & $21 \%$ & $18 \%$ & $18 \%$ & $23 \%$ & $24 \%$ & $25 \%$ & $25 \%$ & $26 \%$ & $27 \%$ & $27 \%$ & $26 \%$ & $24 \%$ \\
\hline
\end{tabular}

4. D.15. Considering that the ROA is the return of the debt and equity holders. Following the same argument as in the previous point, the ROA has little to do with the return to the shareholders. The ROA (NOPAT / (Ebv $+\mathrm{D})$ ) is an accounting ratio, while return is something that refers mainly to changes in expectations.

4. D.16. Using different and inconsistent discount rates for cash flows of different years or for different components of the free cash flow. An example is error 2 in Appendix 2.

4. D.17. Using past market returns as a proxy for required return to equity. Example taken from a valuation performed by an institution: "The opportunity cost of investing in the company could be the return of an investment in the stock exchange. As an indicator of the return of the stock exchange, we use the S\&P 500 index, but with a long time series to eliminate the influence of short-term market movements. S\&P 500 as of June 28, $1999=$ 1,331.35. S\&P 500 as of December 28, $2002=1,457.66$.

$(1,457.66 / 1,331.35)-1=9.5 \%$.

Therefore, the estimated annual cost of equity is: $(1+9.5 \%)^{2}-1=19.9 \%$."

4. D.18. Adding the liquidation value and the present value of cash flows. Example taken from a valuation performed by an institution: "The minimum value of the shares of the 
company is $\$ 20.1$ million, the sum of the liquidation value (\$9.6 million) and the present value of expected cash flows (\$10.5 million)."

4. D.19. Using ad hoc formulas to value intangibles. Example taken from a valuation performed by a financial consultant: "Valuing intangibles is very difficult. But one approximation would be to quantify the guarantees that the shareholders have given to the banks. The company's financial debt is about $\$ 20$ million. We estimate that the bank loans without the shareholders' guarantees could have an additional annual cost of 2.5\%. Quantifying this 2.5\% along 10 years, the additional financial cost will be about $\$ 2$ million. Therefore, $\$ 2$ million is a good approximation of the value of the intangibles."

4. D.20. Arguing that different discounted cash flow methods provide different valuations. All methods always give the same value, as it is shown in chapters 17 and 21 of Fernández (2002). This result is logical, since all the methods analyze the same reality under the same hypotheses; they differ only in the cash flows taken as the starting point for the valuation.

4. D.21. Adding the value of assets that are necessary in order to obtain the cash flows to the present value of the flows. Example: The explosions of some military exercises coincided with the death of several breeding female rabbits from a nearby farm. The owner of the farm claimed compensation from the Ministry of Defense for each dead female rabbit, as follows:

Damage for each dead breeding female:

\begin{tabular}{|c|c|}
\hline - $\quad$ Number of lost litters & 3.5 \\
\hline - Number of rabbits per litter & 8 \\
\hline - Lost rabbits (total) & 28 \\
\hline - Medium weight of each rabbit sold at the age of 3 months $(\mathrm{kg})$ & 2.167 \\
\hline - $\quad$ Medium price per $\mathrm{kg}$ & 1.8 \\
\hline - Sale value of unsold dead rabbits & 109.22 \\
\hline - Minus value of the food that the rabbits would have eaten $(€ 0.70)$ & -19.6 \\
\hline A Total loss due to 28 unsold rabbits because of their mother's death & $€ 89,62$ \\
\hline B. Plus the cost of buying a breeding female & $€ 18,03$ \\
\hline Total damage for each dead breeding female ( $A+B)$ & $€ 107,65$ \\
\hline
\end{tabular}

How did he obtain the number of lost births? If a dead female rabbit had not been replaced by buying another 5-month-old female (at a market price of €18.03), but it could have been obtained by inseminating one of the existing females in the farm, the necessary time to its first litter would be 7 months (delay between the insemination of the mother and the birth of the litter: 1 month; from the birth of the litter until it can be inseminated: 5 months; from that insemination until the first birth: 1 month).

Given that the period between two inseminations is 2 months (one until the birth and the other for lactation), the number of lost births would be: $7 / 2=3.5$.

How did he obtain the value of the food? The rabbits are fed by their mothers during the first month. They remain being fed in the farm another month, and then they are sold in the market when two months old. The cost of the food during that particular month is $€ 0.70 /$ rabbit.

However, despite all this complication, the total number of breeding females stayed the same... which means that the dead breeding females could simply have been replaced by buying 5 -month-old females. 
4. D.22. Having an incorrect notion of the meaning of efficient markets. Spotted in a book about valuation: "According to the efficient market hypothesis, the expected value of the future changes of the share prices is zero. The reason is clear: if the market is efficient, the best estimator of the future price is today's price, because the price today incorporates all available information."

This is an error. The relationship between the expected value of the shares (E) of two consecutive years and the expected equity cash flow (ECF) is:

$E_{t}=E_{t-1}\left(1+K_{t}\right)-E_{t}$. The expected value of the shares is constant $\left(E_{t}=E_{t-1}\right)$ if $E_{C F}=E_{t-1} K_{t}$. It happens only in perpetuities with zero growth.

4. D.23. Applying a discount when valuing diversified companies. This is an error as shown by my colleagues Campa and Kedia (2002).

4. D.24. Wrong arbitrage arguments. Example: If you buy a share today and finance the purchase $100 \%$ with debt, the expected value of this portfolio in a year is $S_{0}(1+K e)-S_{0}(1+K d)$. $\mathrm{S}_{0}$ is the share price today, Ke is the required return, and $\mathrm{S}_{0}(1+\mathrm{Kd})$ is the amount that you will have to pay to cancel the debt. Obviously, $\mathrm{S}_{0}(1+\mathrm{Ke})=\mathrm{E}\left\{\mathrm{S}_{1}+\mathrm{ECF}_{1}\right\}$, being $\mathrm{E}\left\{\mathrm{ECF}_{1}\right\}$ the expected value of the dividends and $E\left\{S_{1}\right\}$ the expected value of the share in year 1 . A valuation expert maintained that to avoid arbitrage opportunities, $\mathrm{S}_{0}(1+\mathrm{Ke})=\mathrm{S}_{0}(1+\mathrm{Kd})$, and as a consequence, Ke $=\mathrm{Kd}$. That is wrong because we cannot make arbitrage profits with expected values.

4. D.25. Adding a control premium when it is not appropriate. The control of a company only has some value if the buyer expects higher cash flows or smaller risk than the current owners.

4. D.26. Stating that the value of the shares of a company is their liquidation value. This affirmation was made by a professor when calculating the adjusted book value of the shares of El Corte Inglés.

4. D.27. Not taking into consideration the treasury stock. In order to calculate the value of one share, the value of all the shares should be divided by the shares which are not included in the treasury stock - a share in the treasury stock (or reacquired stock) is, for these purposes, non-existent.

\section{Errors when interpreting the valuation}

The following errors arise from forgetting that the value resulting from any valuation is always contingent on a set of expectations (about the future of the company, the industry, the country, and the world economy) and on an assessment of the risk of the company.

5. A. Confusing Value with Price. The value is always contingent on a set of expectations. A company normally will have different values for different buyers. If the price paid in an acquisition is equal to the value for the buyer, then the value created by the acquisition equals zero. On the other hand, don't forget that value is normally a number in a spreadsheet, while price is very often cash. There is a difference between $\$ 20$ million cash and $\$ 20$ million written in a spreadsheet!

5. B. Asserting that a valuation is "a scientific fact, not an opinion." A valuation has little to do with science; a valuation is always an opinion.

5. C. A valuation is valid for everybody. A company will normally have a different value for the buyer and for the seller.

5. D. A company has the same value for all buyers. A company will normally have different values for different buyers. 
5. E. Confusing strategic value for a buyer with fair market value. The strategic value contains the extra value (normally due to additional cash flow generation) that a given buyer thinks that he may get from a company on top of what might be "normal" for other buyers.

5. F. Considering that goodwill includes the brand value and the intellectual capital. Goodwill is merely the difference between the price paid and the book value. There are many cases (especially when interest rates are high) in which the price paid is less than the book value. An example is Appendix 2: the book value of the shares was 10.76 million euros, and the shares were sold for 5 million euros. Does that mean that Pepsi's brand value or the value of the "intellectual capital" was negative?

5. G. Forgetting that a valuation is contingent on a set of expectations about cash flows that will be generated and about their riskiness. This is particularly important in certain acquisition processes. Example: the valuation that a bidder had of the shares of a company was \$273 million. But there was another bidder that offered \$325 million. The CEO of the first company asked its CFO to prepare another valuation with a minimum of $\$ 350$ million. The CFO increased expected sales, expected margins and expected residual growth and got a valuation of $\$ 368$ million. The CEO offered $\$ 350$ million, got the company and organized a celebration party.

\section{H. Asserting that "a valuation is the starting point of a negotiation".}

According to a Spanish saying, "only the stupid mix value with price."

\section{I. Asserting that "a valuation is 50\% art and 50\% science".}

A good valuation is basically an exercise of common sense.

\section{Organizational errors}

6. A. Valuation without any check of the forecasts provided by the client. Often, the valuer will ask the client for a forecast of the company's cash flows (or a P\&L forecast). And often, the valuer will use this forecast (which is sometimes no better than a letter to Santa Claus), without checking its validity. An example: A soft drinks bottling and distribution company gave an eight-year forecast in which sales doubled every four years. However, the headcount was assumed to remain constant and no significant investments were planned.

6. B. Commissioning a valuation from an investment bank and not having any involvement in it. A fairly common error is to assign a valuation to an investment bank and wait for the valuation report. Obviously, any such valuation will merely be the value of the company according to the investment bank's forecast (regarding the economy, the industry and the company) and the investment bank's appraisal of the riskiness of the company.

6. C. Involving only the finance department in valuing a target company. To obtain a decent valuation, the sales, production, marketing, personnel, strategy, and legal departments also need to be involved.

6. D. Assigning the valuation of a company to an auditor. The Law on Reform Measures of the Financial System (Law 44/2002, 22/11/2002, published in the Official Spanish 
Gazette 23/11/2002) sets that the fair value ("valor razonable") should be determined by an auditor, different from the company's auditor, who, under demand from any person interested, should be appointed by the company's management.

The modified Law of Corporations (1564/1989) already stated in Article 64.1 that the "real value" should be determined by the company's auditor or, under a petition presented by any person interested and provided the company was not compelled to verify its annual accounts, by an a auditor appointed by the Trade Register director or officer of the registered office of the company.

The text of this law looks rather strange if we consider the fact that auditors are experts in accountancy but not in company valuation (unless they have studied and have experience of company valuation - in which case that knowledge is the relevant qualification for performing company valuations; not the fact that they are auditors). According to the Dictionary of the Real Academia, auditing is defined as "the revision of the accounting of a company, of a society, etc., done by an auditor." It also defines the term auditor as "one who performs audits". "Valor razonable" is the Spanish translation for "fair value" and it can be defined as the best rational and unbiased estimate of the potential market price of shares.

The content of the above law is equivalent to the next two: "in order to be a centre-forward in a football team you have to be a football manufacturer" and "in order to be able to perform open-heart surgery you have to be a manufacturer of operating theatres." You may find this ridiculous; however, the previous definition of "valor razonable" proposed by the law deserves the same qualification.

These lines are not intended to offend auditors or football manufacturers. A good audit is a highly useful service for our society as well as for the experts in valuation. There are several requirements in order to realize a good audit: a lot of initial training, updating that training, deep revisions of the accounts of the companies, and the courage to point out eventual disagreements to the client. It is a very important work, but it bears no relation to the valuation (just like manufacturing footballs and being a centre-forward). The auditing looks basically at the past (the accountancy of a company is one of its possible histories), while the valuation is strongly related to the future.

Consider the following examples of the effects of this law. Recently, some experts in auditing stated that the fair value of the shares of unlisted companies (either large or small) is the same as their book value. These valuations include statements as: "stating that a share's value is equal to its book value is a certainty;" "the theoretic book value of a share which results from its consolidated balance sheet is the most representative for the real value of the share;" "the theoretic book value is not subject to financial jugglery and, therefore, it represents the best and most objective estimate of the fair value of the shares."

A simple look at the value of the Spanish shares listed on the continuous market is sufficient in order to notice that, on average, the price of shares is 4,6 times their book value. There was just one company whose share price was below its book value. 85\% of the companies had share prices above the double of their book values, $60 \%$ of the companies had share prices representing more than three times as much as their book values and 38\% of the companies had share prices of more than four times as much as their book values. Consequently, stating that the fair value of the shares of a company is equal to their book value is similar to stating that the height of an adult Spanish individual is 38 centimeters (if the average height is of 175 centimeters, then $38=174 / 4.6$ ). Isn't it surprising? This is just an example of the type of surprise that such a law provides us with, in giving auditors an exclusive right to establish the fair value of the shares. 


\section{APPENDIX 1}

List of the 110 errors

The most common errors are in italics

1. Errors in the discount rate calculation and concerning the riskiness of the company

A. Wrong risk-free rate used for the valuation

1. Using the historical average of the risk-free rate at the actual risk-free rate.

2. Using the short-term government bond rate.

3. Wrong calculation of the real risk-free rate.

B. Wrong beta used for the valuation

1. Using the historical industry beta, or the average of the betas of similar companies, when the result goes against common sense.

2. Using the historical beta of the company when the result goes against common sense.

3. Assuming that the beta calculated from historical data captures the country risk.

4. Using the wrong formulae for lever and unlever the beta.

5. Arguing that the best estimation of the beta of an emerging market company is the company's beta with respect to the S\&P 500 .

6. Using the beta of the acquiring company when valuing an acquisition.

7. Using the so-called "book value beta".

8. Forgetting the beta of the debt when levering the beta of the shares.

9. Calculating the beta using strange formulae.

C. Wrong market risk premium used for the valuation

1. The required market risk premium is equal to the historical equity risk premium.

2. The required market risk premium is equal to zero.

3. Assuming that the required market risk premium is the expected risk premium.

4. Using historical, implicit, expected and required risk premiums interchangeably.

5 . Using a risk premium recommended by a text book even though it goes against common sense.

D. Wrong calculation of WACC

1. Using the Wrong definition of WACC.

2. The debt-to-equity ratio used to calculate the WACC is different than the debt-to-equity ratio resulting from the valuation.

3. Using discount rates lower than the risk-free rate.

4. Using the statutory tax rate, instead of the effective tax rate of the levered company.

5. Valuing all the different businesses of a diversified company using the same WACC (same leverage and same Ke).

6. Considering that WACC / (1-T) is a reasonable return for the company stakeholders.

7. Using the wrong formula for the WACC when the value of debt is not equal to its book value.

8. Calculating the WACC assuming a capital structure and deducting the current debt from the enterprise value.

9. Calculating the WACC using book values of debt and equity.

10. Calculating the WACC using strange formulae.

E. Wrong calculation of the value of tax shields

1. Discounting the tax shield using the required return to unlevered equity.

2. Using odd or ad-hoc formulae.

3. Using the Modigliani-Miller formula when it is not appropriate.

4. Using the Milles-Ezzell formula when it is not appropriate.

F. Wrong treatment of country risk

1. Not considering the country risk, arguing that it is diversifiable.

2. Assuming that a disaster in an emerging market will increase the calculated beta, in relation to the S\&P 500, of the companies in that country.

3. Assuming that an agreement with a government agency eliminates country risk.

4. Assuming that the beta provided by Market Guide with the Bloomberg adjustment incorporates the illiquidity risk and the small cap premium.

5. Using odd calculations of the country risk premium.

G. Including an illiquidity, small-cap, or specific premium when it is not appropriate

1. Including an odd small-cap premium.

2. Including an odd illiquidity premium.

3. Including a small-cap premium equal for all companies.

\section{Errors when calculating or forecasting the expected cash flows}

A. Wrong definition of the cash flows

1. Forgetting the increase in working capital requirements when calculating cash flows.

2. Considering an increase in the company's cash position or financial investments as an equity cash flow.

3. Errors in the calculation of the taxes that affect the FCF.

4. Expected equity cash flows are not equal to expected dividends plus other payments to shareholders (share repurchases, ...).

5. Considering net income as a cash flow.

6. Considering net income plus depreciation as a cash flow.

7. Considering that the NOPAT flow is a cash.

$B$. Errors when valuing seasonal companies

1. Wrong treatment of seasonal working capital requirements.

2. Wrong treatment of inventories that are cash equivalent.

3. Wrong treatment of seasonal debt.

C. Errors due to not projecting the balance sheets

1. Forgetting balance sheet accounts that affect the cash flows.

2. Considering an asset revaluation as a cash flow.

3. Interest payments are not equal to debt times cost of debt. 


\section{Errors in the calculation of the residual value}

A. Using inconsistent cash flow to calculate the value of a perpetuity.

$B$. The debt-to-equity ratio used to calculate the WACC for discounting the perpetuity is different to the debt-to-equity ratio resulting from the valuation.

C. Using ad hoc formulas that have no economic meaning.

D. Using arithmetic averages instead of geometric averages to assess growth.

E. Calculating the residual value using the wrong formula.

F. Assuming that a perpetuity starts a year before it really starts

\section{Inconsistencies and conceptual errors}

A. Conceptual errors around free cash flow and equity cash flow

1. Considering the cash in the company as an equity cash flow when the company is not going to distribute it.

2. Using real cash flows and nominal discount rates, or vice versa.

3. The free cash flow and the equity cash flow do not satisfy $E C F=F C F+\Delta D-\operatorname{Int}(1-T)$.

B. Errors when using multiples

1. Using the average of multiples extracted from transactions executed over a very long period of time.

2. Using the average of transactions multiples that have a wide dispersion.

3. Using multiples in a way that is inconsistent with their definition.

4. Using a multiple from an extraordinary transaction.

5. Using ad hoc valuation multiples that conflict with common sense.

6. Using multiples without using the common sense.

C. Time inconsistencies

1. Assuming that the equity value will be constant in the future.

2. The Equity value or the Enterprise Value do not satisfy the time consistency formulae.

D. Other conceptual errors

1. Not considering cash flows resulting from future investments.

2. Considering that a change in economic conditions invalidates signed contracts.

3. Considering that the value of debt is equal to its book value, when they are different.

4. Not using the correct formulae when the value of debt is not equal to its book value.

5. Considering that the book value of the shares is a good proxy for their market value.

6. Including the value of real options that have no economic meaning.

7. Considering shared options as one's own.

8. Forgetting to include the value of non-operating assets.

9. Inconsistencies between discount rates and expected inflation.

10. Valuing a holding company assuming permanent losses (without tax savings) in some companies and permanent profits in others.

11. Wrong concept of the optimal capital structure.

12. In mature companies, assuming projected cash flows that are much higher than historical cash flows without any good reason.

13. Assumptions about future sales, margins, etc., that are inconsistent with the economic environment, the industry outlook, or competitive analysis.

14. Considering that the ROE is the return to the shareholders in non-traded companies.

15. Considering that the ROA is the return of the debt and equity holders.

16. Using different and inconsistent discount rates for cash flows of different years or for different components of the free cash flow.

17. Using past market returns as a proxy for required return to equity.

18. Adding the liquidation value and the present value of cash flows.

19. Using ad hoc formulas to value intangibles.

20. Arguing that different discounted cash flow methods provide different valuations.

21 Adding the value of assets that are necessary in order to obtain the cash flows to the present value of the flows.

22. Having an incorrect notion of the meaning of the efficient markets.

23. Applying a discount when valuing diversified companies.

24. Wrong arbitrage arguments.

25. Adding a control premium when it is not appropriate.

26. Stating that the value of the shares of a company is their liquidation value.

27. Not taking into consideration the treasury stock.

\section{Errors when interpreting the valuation}

\section{A. Confusing Value with Price.}

B. Asserting that "a valuation is" a scientific fact, not an opinion.

C. A valuation is valid for everybody.

D. A company has the same value for all buyers.

E. Confusing strategic value for a buyer with fair market value.

F. Considering that the goodwill includes the brand value and the intellectual capital.

G. Forgetting that a valuation is contingent on a set of expectations about cash flows that will be generated and about their riskiness.

$\mathrm{H}$. Asserting that "a valuation is the starting point of a negotiation."

I. Asserting that "a valuation is $50 \%$ art and $50 \%$ science."

\section{Organizational errors}

A. Valuation without any check of the forecasts provided by the client.

B. Commissioning a valuation from an investment bank and not having without any involvement in it.

C. Involving only the finance department in valuing a target company.

D. Assigning the valuation of a company to an auditor 


\section{Appendix 2.}

A valuation containing multiple errors using an ad hoc method

The following is a summary of the valuation of a South European Pepsi-Cola franchise (a bottling plant and a distribution company) made in 1990 by a consulting company. "The term 'value of the shares' is defined as the estimated fair purchase or sale value for a free buyer and a free seller, both of whom are aware of all the relevant legal documents and neither of whom is acting under any kind of duress."

Table A2.1 shows the company's balance sheets and P\&L, actual and as forecast by the financial consulting firm. Table A2.2 shows the valuation of the shares at 21.6 million euros. This figure is obtained by first calculating the expected free cash flows (lines 1-4). Line 5 calculates the present value of the free cash flows 1990-1994 at 17.48\%, which gives 6.3 million euros. Line 6 is the present value of the residual value calculated in lines 11-16. From the resulting value of the firm the debt is deducted and the value of the investments is added to arrive at the figure of 21.6 million euros as the value of the shares.

Table A2.1

Balance sheets and P\&L of BottlingSouth (million euros)

\begin{tabular}{|l|c|c|c|c|c|c|c|c|c|c|c|}
\cline { 2 - 13 } \multicolumn{1}{c|}{} & \multicolumn{4}{c|}{ Actual } & \multicolumn{4}{c|}{ Forecast } \\
\cline { 2 - 13 } \multicolumn{1}{c|}{} & $\mathbf{1 9 8 4}$ & $\mathbf{1 9 8 5}$ & $\mathbf{1 9 8 6}$ & $\mathbf{1 9 8 7}$ & $\mathbf{1 9 8 8}$ & $\mathbf{1 9 8 9}$ & $\mathbf{1 9 9 0}$ & $\mathbf{1 9 9 1}$ & $\mathbf{1 9 9 2}$ & $\mathbf{1 9 9 3}$ & $\mathbf{1 9 9 4}$ \\
\hline Sales & 10.52 & 13.38 & 14.88 & 19.40 & 20.97 & 23.33 & 25.96 & 27.79 & 29.90 & 32.32 & 34.79 \\
\hline Net income & 0.89 & 1.50 & 1.69 & 2.15 & 1.49 & 1.35 & 1.83 & 2.27 & 2.82 & 3.65 & 4.22 \\
\hline
\end{tabular}

\begin{tabular}{|l|c|c|c|c|c|c|c|c|c|c|c|}
\hline Balance sheet & $\mathbf{1 9 8 4}$ & $\mathbf{1 9 8 5}$ & $\mathbf{1 9 8 6}$ & $\mathbf{1 9 8 7}$ & $\mathbf{1 9 8 8}$ & $\mathbf{1 9 8 9}$ & $\mathbf{1 9 9 0}$ & $\mathbf{1 9 9 1}$ & $\mathbf{1 9 9 2}$ & $\mathbf{1 9 9 3}$ & $\mathbf{1 9 9 4}$ \\
\hline Net fixed assets & 4.04 & 5.02 & 5.87 & 7.46 & 9.88 & 11.63 & 12.31 & 13.04 & 13.84 & 14.70 & 15.60 \\
\hline WCR & 1.17 & 1.81 & 2.25 & 3.34 & 3.95 & 4.68 & 5.19 & 6.11 & 7.18 & 9.05 & 10.69 \\
\hline Total assets & 5.20 & 6.83 & 8.12 & 10.80 & 13.83 & 16.31 & 17.50 & 19.15 & 21.01 & 23.75 & 26.29 \\
\hline Financial Debt & 1.28 & 1.60 & 1.54 & 2.40 & 4.13 & 5.55 & 5.55 & 5.55 & 5.55 & 5.55 & 5.55 \\
\hline Net worth & 3.92 & 5.24 & 6.58 & 8.40 & 9.70 & 10.76 & 11.95 & 13.60 & 15.46 & 18.20 & 20.74 \\
\hline
\end{tabular}

The risk-free interest rate at the time of the valuation was $13.3 \%$ and the year-on-year inflation rate was $6.9 \%$. Expected inflation was 5\%.

This valuation contains at least five mistakes.

Table A2.2

Valuation of the shares of BottlingSouth (million euros)

\begin{tabular}{|c|c|c|c|c|c|c|}
\hline & Million euros & 1990 & 1991 & 1992 & 1993 & 1994 \\
\hline 1 & Net income & 1.83 & 2.27 & 2.82 & 3.65 & 4.22 \\
\hline 2 & + depreciation & 0.26 & 0.25 & 0.23 & 0.21 & 0.23 \\
\hline 3 & - investments in fixed assets & 0.93 & 0.98 & 1.03 & 1.08 & 1.13 \\
\hline 4 & = FREE CASH-FLOW & 1.15 & 1.54 & 2.02 & 2.78 & 3.32 \\
\hline 5 & Present value of free cash flows at $17.48 \%$ & 6.3 & \multirow{6}{*}{\multicolumn{2}{|c|}{$=35.3 /(1,122)^{5}$}} & & \\
\hline 6 & Present value of the residual value at $12.2 \%$ & 19.8 & & & & \\
\hline 7 & Enterprise Value & 26.1 & & & & \\
\hline 8 & - Financial Debt & -5.6 & & & & \\
\hline 9 & + Value of financial investments & 1.0 & & & & \\
\hline 10 & Equity value & 21.6 & & & & \\
\hline
\end{tabular}

Residual value

\begin{tabular}{|c|c|c|c|}
\hline 11 & Market value of fixed assets in 1989 & 17.43 & \\
\hline 12 & + New investments in fixed assets in 1990-1994 & 5.1 & \\
\hline 13 & - Loss in the value of fixed assets in 1990-1994 & -3.00 & \\
\hline 14 & + Working Capital Requirements in 1994 & 10.7 & \\
\hline 15 & = Substantial value in 1994 & 30.3 & \\
\hline 16 & Enterprise value in 1994 & 35.3 & $=30.3+3.587 \times(4.22-30.3 \times 0.0933)$ \\
\hline
\end{tabular}


Errors:

1. Free cash flow calculation. The free cash flow is miscalculated because it includes interest (part of net income) and it does not include the increases in WCR. Table A2.3 shows the impact of these two corrections on the free cash flow.

Table A2.3

Corrections to the free cash flow calculation of Table A2.2

\begin{tabular}{|l|c|c|c|c|c|}
\cline { 2 - 6 } \multicolumn{1}{c|}{} & $\mathbf{1 9 9 0}$ & $\mathbf{1 9 9 1}$ & $\mathbf{1 9 9 2}$ & $\mathbf{1 9 9 3}$ & $\mathbf{1 9 9 4}$ \\
\hline Wrong Free Cash Flow (line 4 of Table 9) & 1.15 & 1.54 & 2.02 & 2.78 & 3.32 \\
\hline - increase in Working Capital Requirements & 0.51 & 0.92 & 1.06 & 1.87 & 1.64 \\
\hline + Interest expenses x (1 - 35\%) & 0.54 & 0.54 & 0.54 & 0.54 & 0.54 \\
\hline Corrected Free Cash Flow & 1.18 & 1.16 & 1.50 & 1.45 & 2.22 \\
\hline
\end{tabular}

2. The free cash flow of the years $1990-1994$ is discounted at a higher rate (17.48\%) than the residual value in $1994(12.25 \%)$

3. The discount rate used for the residual value in 1994 (12.25\%) is lower than the risk-free rate (13.3\%).

4. The calculation of the residual value is very curious, but wrong. If we calculate the residual value as a perpetuity that grows at a rate $g$ based on the corrected free cash flow for 1994 (2.22), we get a rate of growth of $10.5 \%$. Obviously, this is absurd:

$$
\text { Residual value }=35.3=2.22(1+\mathrm{g}) /(0.1748-\mathrm{g}) . \mathrm{g}=10.5 \%
$$

5. Over-optimistic net income and cash flow forecasts. One way to see just how over-optimistic they were is to compare the growth of the dividends that the company actually paid out over the period 1984-1989 with the dividend forecasts implicit in Table A2.2 (see Table A2.4). Over the previous 5 years dividends had grown from 0.22 million to 0.3 million, whereas over the next 5 years they were projected to grow from 0.3 million to 1.68 million. And we should not forget that this is a soft drinks company operating in a very mature industry.

\section{Table A2.4}

Dividends paid until 1989 and implicit dividends in the projections of Table A2.2

\begin{tabular}{|l|c|c|c|c|c|c|c|c|c|c|c|}
\hline (Million euros) & 1984 & 1985 & 1986 & 1987 & 1988 & 1989 & 1990 & 1991 & 1992 & 1993 & 1994 \\
\hline Dividends & 0.22 & 0.18 & 0.35 & 0.32 & 0.19 & 0.30 & 0.64 & 0.62 & 0.96 & 0.91 & 1.68 \\
\hline
\end{tabular}

\section{What happened?}

The consulting firm that produced the valuation was asked to manage the sale at the price of $€ 21.6$ million, but they replied that they only did valuations. In the end, after various long and drawn-out negotiations, the company's shares were eventually sold for 5 million euros. Note that this is not such a small amount: it assumes, if the dividends are discounted at 20\%, that the 1989 dividends will grow indefinitely at $13.2 \%$. $5=0.3 \times 1.132 /(0.2-$ 0.132).

Table A2.5 shows the company's net income after the valuation. Note the big difference between these figures and the forecasts in Table A2.1.

Table A2.5.

Net income of BottlingSouth after the valuation (million euros)

\begin{tabular}{|l|c|c|c|c|c|c|c|c|}
\cline { 2 - 8 } \multicolumn{1}{c|}{} & $\mathbf{1 9 9 0}$ & $\mathbf{1 9 9 1}$ & $\mathbf{1 9 9 2}$ & $\mathbf{1 9 9 3}$ & $\mathbf{1 9 9 4}$ & $\mathbf{1 9 9 5}$ & $\mathbf{1 9 9 6}$ & $\mathbf{1 9 9 7}$ \\
\hline Net income & 1.08 & 1.30 & 0.59 & 0.64 & 1.30 & 1.08 & 0.59 & 1.20 \\
\hline
\end{tabular}




\section{References}

Brealey, R.A. and S.C. Myers (2000), "Principles of Corporate Finance," sixth edition, McGrawHill, New York.

Bruner, R.F., R.M. Conroy, J. Estrada, M. Kritzman, and Wei Li (2002), "Introduction to 'Valuation in Emerging Markets'," Emerging Markets Review, Vol. 3, No 4, December, pp. 310-324.

Campa, J.M. and P. Fernández (2004), “Are calculated betas good for anything?,” IESE Working Paper.

Campa, J. M., and Simi Kedia (2002), "Explaining the Diversification Discount," Journal of Finance, Vol. 57, No. 4, pp. 1731-1762.

Copeland, T. E., T. Koller, and J. Murrin (2000), "Valuation: Measuring and Managing the Value of Companie,". third edition, John Wiley and Sons, New York.

Damodaran, A. (1994), “Damodaran on Valuation,” John Wiley and Sons, New York.

Damodaran, A. (2001), “The Dark Side of Valuation,” Financial Times-Prentice Hall, New York.

Dimoson, E., P. March, and M. Staunton (2002), "Global Evidence on the Equity Risk Premium," Journal of Applied Corporate Finance, September.

Durbin, E., and D. Ng (1999), “Uncovering Country Risk in Emerging Market Bond Prices," Board of Governors of the Federal Reserve System, International Finance Discussion Paper, 639, July.

Estrada, J. (2000), "The Cost of Equity in Emerging Markets: A Downside Risk Approach," Emerging Markets Quarterly, Fall, pp. 19-30.

Fernández, Pablo (2006a), "The Value of Tax Shields Depends Only on the Net Increases of Debt," IESE Business School Working Paper No. 613. Available at SSRN: http://ssrn.com/abstract=827351.

Fernández, Pablo (2006b), "Equity Premium: Historical, Expected, Required and Implied," IESE Working Paper No. 661. Available at SSRN: http://ssrn.com/abstract=933070

Fernández, Pablo (2006c), "The Equity Premium in Finance and Valuation Textbooks," IESE Working Paper No. 657. Available at SSRN: http://ssrn.com/abstract=934324

Fernández, Pablo (2005), "Equivalence of Ten Different Methods for Valuing Companies by Cash Flow Discounting," International Journal of Finance Education, Volume 1, Issue 1, pp. 141-168

Fernández, P. (2004a), "The value of tax shields is NOT equal to the present value of tax shields," Journal of Financial Economics, Vol. 73/1 (July), pp. 145-165.

Fernández, P. (2004b), "The Value of Tax Shields and the Risk of the Net Increase of Debt," http://ssrn.com/abstract $=506005$

Fernández, P. (2004c), “Valoración de Empresas,” third edition, Ediciones Gestión 2000, Barcelona.

Fernández, P. (2003), "How to value a seasonal company discounting cash flows," SSRN Working Paper. 
Fernández, P. (2002), "Valuation Methods and Shareholder Value Creation," Academic Press, San Diego, CA.

Godfrey, S. and R. Espinosa (1996), "A Practical Approach to Calculating Costs of Equity for Investment in Emerging Markets,” Journal of Applied Corporate Finance, Fall, pp. 80-89.

Haight, G. Timothy (2005), "Real Estate Investment Handbook," John Wiley and Sons, incorporated, Hoboken, NJ, USA.

Hamon, J., and B. Jacquillat (1999), "Is there Value-added information in Liquidity and Risk Premiums?,” European Financial Management, November, 5(3), pp. 369-393.

Kaminsky, G., and S.L. Schmukler (2002), "Emerging Market Instability: Do Sovereign Ratings Affect Country Risk and Stock Returns,?” Bank Economic Review, 16(2), pp. 171-195.

Knetz, P.J. and M.J. Ready (1997), "On the robustness of the size and book-to-market in crosssectional regressions," The Journal of Finance, September, 52(4), pp. 1355-1382.

Lessard, D. (1996), "Incorporating Country Risk in the Valuation of Offshore Projects," Journal of Applied Corporate Finance, Fall, pp. 52-63.

Mehra, R. (2003), “The equity premium: Why is it a puzzle?," Financial Analysts Journal, January/February, pp. 54-69.

Mehra, R. and E. Prescott (1985), "The equity premium: A puzzle," Journal of Monetary Economics 15(2), pp. 145-161.

Penman, S. H. (2001), "Financial Statement Analysis and Security Valuation," McGraw-Hill, New York.

Ruback, R. (1986), "Calculating the Market Value of Risk-Free Cash Flows," Journal of Financial Economics, March, pp. 323-339.

Ruback, R. (1995), “A note on capital cash flow valuation”, Harvard Business School, Case No. 9-295-069.

Ruback, R. (2002), "Capital cash flows: a simple approach to valuing risky cash flows", Financial Management 31, pp. 85-103.

Scholes, M. and J.T. Williams (1977), "Estimating Betas from Nonsynchronous Data," Journal of Financial Economics, December, 5(3), pp. 309-327.

Siegel, Jeremy (1998), "Stocks for the Long Run," second edition, Irwin, New York.

Siegel, Jeremy J. (1999), "The Shrinking Equity Premium," Journal of Portfolio Management, Fall, pp. 10-17.

Stowe, J.D., T.R. Robinson, J.E. Pinto, and D.W. McLeavey (2002), "Analysis of Equity Investments: Valuation," Association for Investment Management and Research, Baltimore.

Wang, X. (2000), "Size Effect, Book-to-Market Effect, and Survival," Journal of Multinational Financial Management, September-December, 10, pp. 257-273. 